\title{
Icings along the Trans-Alaska Pipeline Route
}

GEOLOGICAL SURVEY PROFESSIONAL PAPER 979

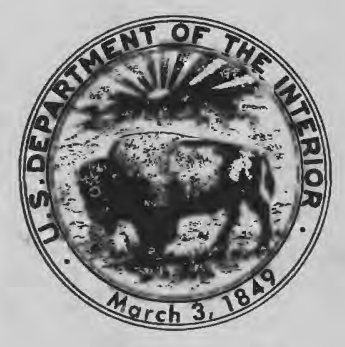



ICINGS ALONG THE TRANS-ALASKA PIPELINE ROUTE 


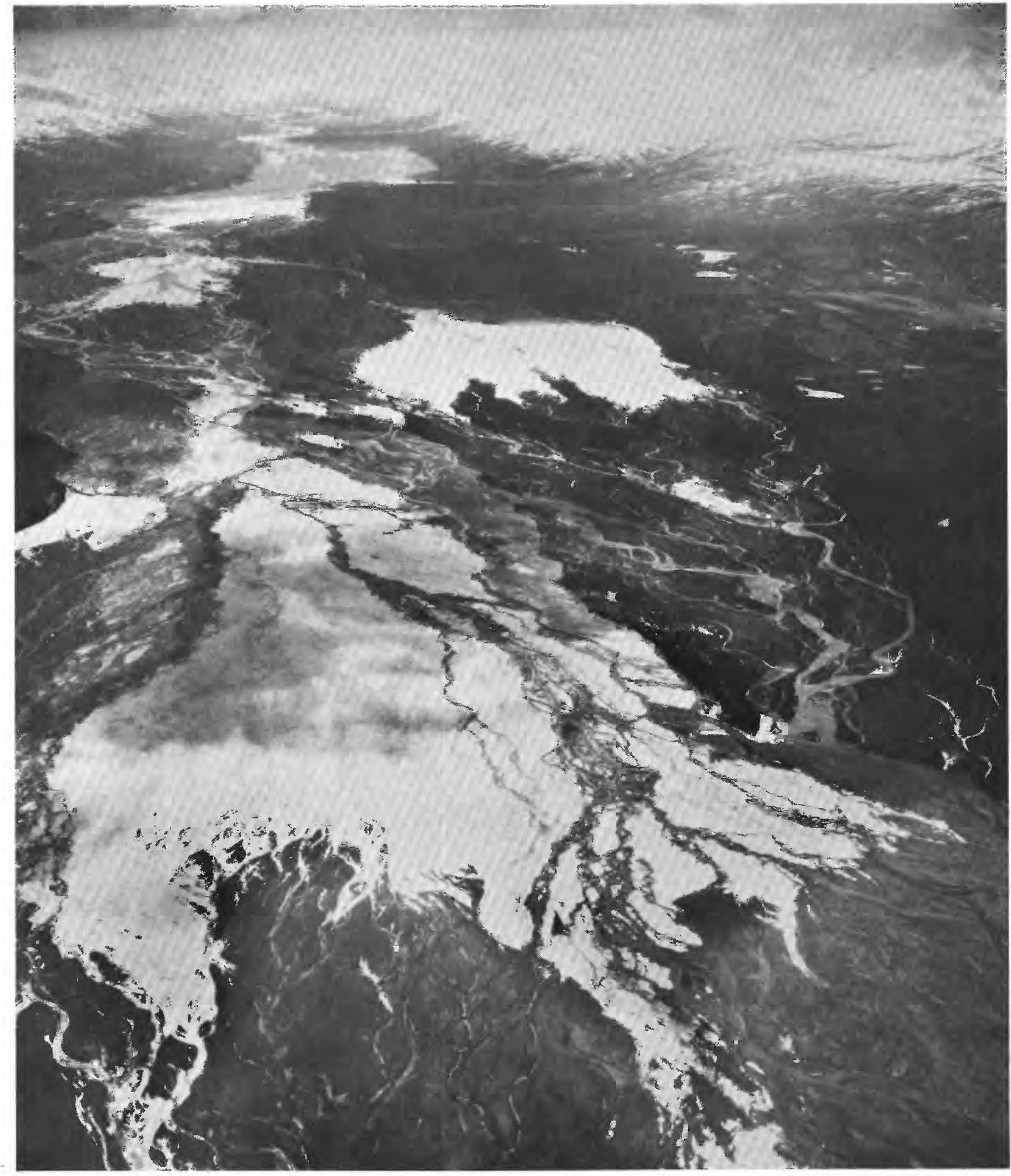

South of Black Rapids the pipeline crosses the active flood plain of the Delta River where extensive icings form annually. 


\section{Icings along the \\ Trans-Alaska Pipeline Route}

By CHARLES E. SLOAN, CHESTER ZENONE, and LAWRENCE R. MAYO

GE OLOGICA L S URVEY PROFESS I O A L PA PER 979

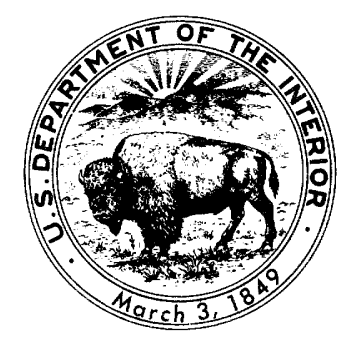




\title{
UNITED STATES DEPARTMENT OF THE INTERIOR
}

\author{
THOMAS S. KLEPPE, Secretary
}

\section{GEOLOGICAL SURVEY}

\section{E. McKelvey, Director}

Library of Congress Cataloging in Publication Data

Sloan, Charles E. $\quad 1930-$

Icings along the trans-Alaska pipeline route.

(Geological Survey Professional Paper 979)

Bibliography: p. 10

Supt. of Docs. no.: $\quad$ 19.16:979

1. Ice-Alaska. 2. Alaska pipeline. I. Zenone, Chester, joint author. II. Mayo, Lawrence R., joint author. III. Title. IV. Series: United States Geological Survey Professional Paper 979. GB2425.A4S56 $551.3^{\prime} 4$ $76-608208$

For sale by the Superintendent of Documents, U.S. Government Printing Office Washington, D.C. 20402

Stock Number 024-001-02883-3 


\section{CONTENTS}

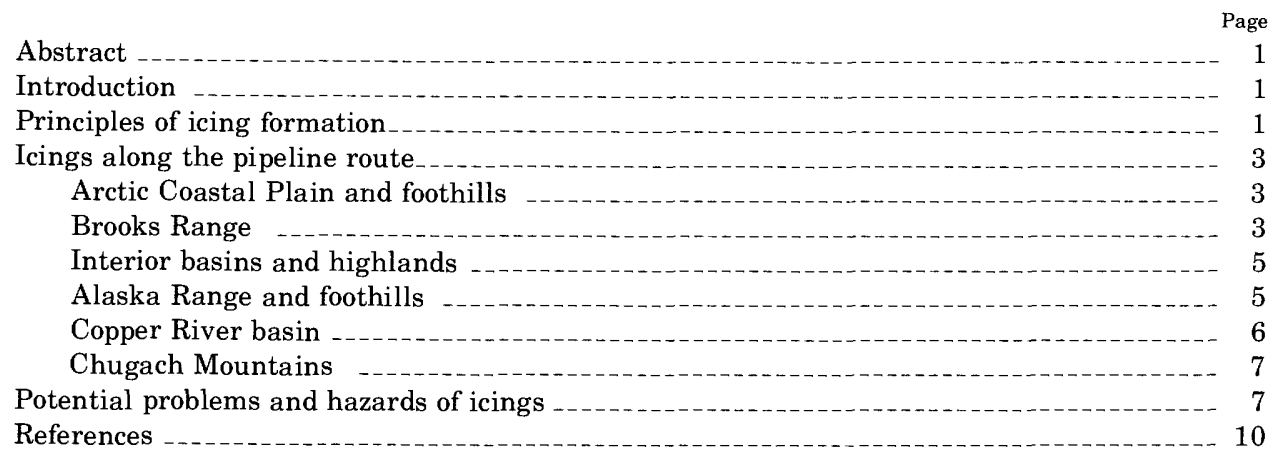

\section{ILLUSTRATIONS}

Frontispiece. Photograph showing the pipeline crossing the active flood plain of the Delta River where extensive icings form annually.

FigURE 1. Index map showing route of the trans-Alaska pipeline and location of maps showing icings

2-6. Photographs showing:

2. Flood-plain icings on the Delta River and tributaries

3. Icing mounds on Trims Creek near pipeline crossing, Delta River valley

4. Fractured icing mound on Dietrich River . . .

5. Upheaved ice and soil block from exploded hillside icing mound in Fish Creek valley

6. Hillside spring in Brooks Range near Ivishak River ......

7. Map showing distribution of icings along the trans-Alaska pipeline route in the Beechey Point quadrangle

8. Map showing distribution of icings along the trans-Alaska pipeline route in the Sagavanirktok quadrangle

9. Photographs showing ERTS-1 images of Sagavanirktok River basin taken on March 31, 1973 and August 4 , 1973

10. Photograph showing Echooka River icing, July 11, 1972

11. Map showing distribution of icings along the trans-Alaska pipeline route in the Philip Smith quadrangle

12. Photograph showing icing on alluvial fan at Galbraith Lake

13. Photograph showing icings in braided reaches of Atigun River

14. Map showing distribution of icings along the trans-Alaska pipeline route in the Chandalar and Wiseman quadrangles

15. Photographs showing icings on the Dietrich River flood plain

16. Photograph showing alluvial fan in Dietrich River valley upstream from Snowden Creek

17. Map showing distribution of icings along the trans-Alaska pipeline route in the Bettles quadrangle .

18. Map showing distribution of icings along the trans-Alaska pipeline route in the Tanana and Livengood quadrangles

19. Photograph showing channel and hillside icings along Aggie Creek in Yukon-Tanana Uplands north of Fairbanks

20. Map showing distribution of icings along the trans-Alaska pipeline route in the Livengood and Fairbanks quadrangles

21. Map showing distribution of icings along the trans-Alaska pipeline route in the Big Delta quadrangle

22. Photograph showing thermal infrared image of icings along Minton Creek

23. Photograph showing icings in flats north of Shaw Creek

24. Map showing distribution of icings along the trans-Alaska pipeline route in the Mt. Hayes quadrangle

25-27. Photographs showing:

25. Flood-plain icings along Delta River

26. Flood-plain icing in Delta River valley upstream from Miller Creek

27. Icing in Phelan and McCallum Creeks 
28. Cross section through icing at mouth of Phelan Creek

29. Photograph showing icing on Gunn Creek

30. Map showing distribution of icings along the trans-Alaska pipeline route in the Gulkana quadrangle

31. Map showing distribution of icings along the trans-Alaska pipeline route in the Valdez quadrangle

32. Photograph showing icing formed from ground-water seepage at face of gravel pit near Little Tonsina River 


\title{
ICINGS ALONG THE TRANS-ALASKA PIPELINE ROUTE
}

\author{
By Charles E. Sloan, Chester Zenone, and Lawrence R. Mayo
}

\begin{abstract}
The location and extent of icings observed during six winters, 1969 to 1974 , along the trans-Alaska pipeline route are shown on a series of maps and photographs. Large flood-plain icings occur in the braided river channels of the Sagavanirktok, Atigun, Dietrich, and Delta Rivers. Numerous lesser stream and hillside icings also occur along the pipeline route. Construction of the pipeline, roads, pumping stations, and training structures will displace some existing icings and will create new icings. Icings may cause problems such as flooding and erosion when they form on or near the pipeline, roads, and other pipeline facilities.
\end{abstract}

\section{INTRODUCTION}

A 48-inch (122-cm) diameter pipeline to transport petroleum from the Prudhoe Bay area on Alaska's North Slope to the ice-free port of Valdez in Prince William Sound is now under construction. The northsouth route of the pipeline (fig. 1) transects the major physical features and climatic zones of Alaska, and thus a wide range of hydrologic conditions will be encountered. This report discusses icings, also called aufeis, which are masses of ice formed by the overflow and subsequent freezing of sheets of surface water and emerging ground water. Icings can cause severe problems when they form on or near highways, airfields, or other structures. Some of these problems may be (a) the diversion of surface water by the ice and the consequent flooding and erosion by ice and water and (b) impaired traffic flow on surface transportation routes.

This report also discusses the distribution and general types of icings along the pipeline route. The severity of icing problems that may be found during the construction and operation of the pipeline system is related to the character of the icings within any section of the route.

The aerial observations and photography upon which this report is based were obtained principally during light-aircraft flights along the trans-Alaska pipeline route during the months of March, April, or May in the years 1969-74. Observations were not made on the same date each year; flight lines, altitudes, snow cover over icings, and weather conditions (thus the visibility) differed somewhat for each set of observations. The maps are a compilation of all icing observations made during the 6-year period. Not all icings shown on the maps were present on any given date. However, nearly all icings shown occurred each winter. Some of the smaller icings did not form annually, and all icings varied in areal extent and thickness from year to year.

Satellite and thermal infrared imagery was examined for evidence of winter overflowing of rivers, of ice remaining in early summer, and of midwinter temperature anomalies. The aerial observations of icings along the pipeline corridor confirmed that the remote sensing techniques show icings. The 6-year record of observations indicates that not all icings can be observed on one airplane trip; likewise, no one set of remote sensing imagery shows all icings or the maximum extent of icings. The remote sensing imagery did not reveal any unknown or unsuspected icing areas along the pipeline corridor.

Periodic icing observations and inventories should be continued during the construction and operation phases of the trans-Alaska pipeline system. Such a monitoring program will permit the detection of significant changes in natural icings and the initiation of any new icings along the pipeline route.

For those readers who may prefer to use metric units rather than English units, the conversion factors for the terms used in this report are listed below:
Multiply English units By To obtain metric units
inches (in.) $\quad 2.540$ centimetres $(\mathrm{cm})$
feet $(\mathrm{ft}) \quad 0.3048$ metres $(\mathrm{m})$

\section{PRINCIPLES OF ICING FORMATION}

An icing is a mass of surface ice formed during the winter by the successive freezing of sheets of water that seep from the ground, from a river, or from a spring (A. M. Chekotillo, 1940, in Carey, 1970). Carey (written commun., 1967, 1968) has collected and analyzed data on icings in Alaska. He has discussed in detail the origin, formation, engineering significance, and techniques for study and control of icings (1973) and has compiled an annotated bibliography on these topics (1970). The following general statements about icings are derived from these publications and from the authors' observations. 


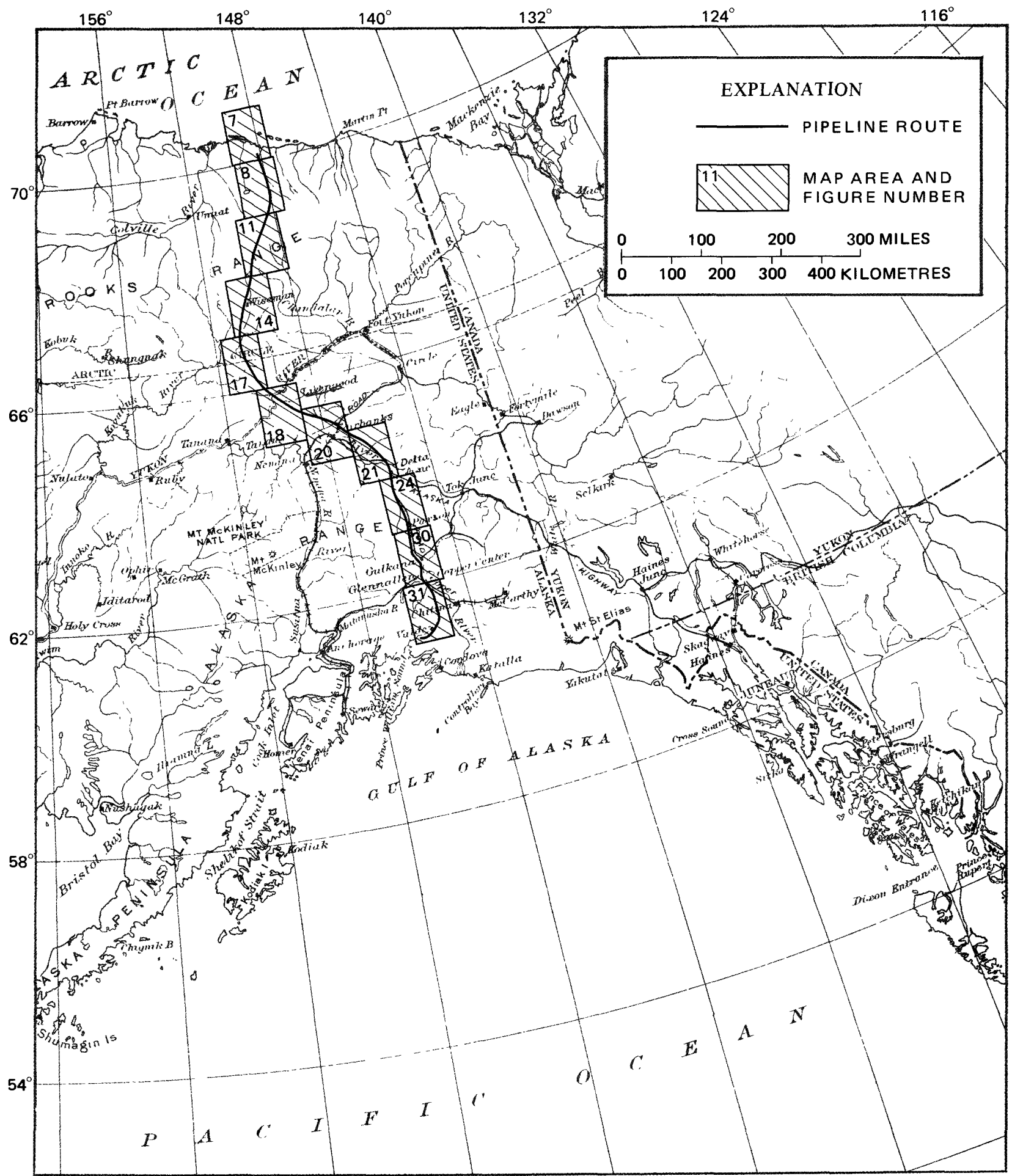

Base from U.S. Geological Survey Alaska Map C

FIGURE 1.-Route of the trans-Alaska pipeline and location of maps showing icings. 
The complex interaction of several factors, rather than a single factor, controls the incidence of icings. At any site, topographic, geologic, hydrologic, and meteorologic factors determine the dynamics, regime, and magnitude of the icing process.

Icings occur on streams when channel ice thickens until the channel is completely frozen or flow is restricted beneath the ice. Hydrostatic pressure increases beneath ice in constricted channels and may cause ice to be lifted temporarily (Kane and others, 1973). Water eventually breaks through the ice cover or flows out at the edge of the ice sheet. The water then spreads out and freezes. Icings thicken primarily from the freezing of overflowing water. To a lesser extent ice thickness is increased by the freezing of water within or below the main ice mass.

Thick flood-plain icings commonly form on braided rivers (fig. 2) because the channels are shallow and readily frozen. On the other hand, icings can be the cause of braided channels by diverting flow during spring breakup and also by inhibiting plant growth on the flood plain. Icings are not common on large rivers where the flow is confined to a narrow or single channel because of the greater channel depth. Icings form readily along small, single, shallow channels in those areas where winter streamflow is sustained by ground water. Large springs are the source of major icings in some river valleys. Small springs and seeps of ground water form small upland or hillside icings.

Icing mounds or hummocks are uplifted ice ridges, broad humps, or smaller conical domes (fig. 3) that are common features on large icings. As ice freezes downward, pockets of water may become isolated. The volume expansion that results from the freezing process in these pockets sharply increases the hydrostatic pressure. Doming may also occur when the hydrostatic pressure due to an increase in discharge or decrease in channel size is sufficient to deform the ice sheet upward at weak places. The pressure is relieved as water bleeds out through radial or ciruclar cracks.

Pressure in icings can result from accumulations of entrapped gas, such as air or methane. Pockets of gas under pressure have been discovered by drilling into domes that show no evidence of overflowing water. Occasionally, relief of gas pressure can occur suddenly and explosively, resulting in displaced and shattered blocks of ice (fig. 4 and 5).

\section{IGINGS ALONG THE PIPELINE ROUTE}

\section{ARCTIC COASTAL PLAIN AND FOOTHILLS}

Large icings near the front of the Brooks Range are fed by springs discharging from carbonate bedrock directly to the river or alluvium in the river bed (fig. 6).

Broad flood-plain icings form on many of the braided reaches of the Sagavanirktok and Ivishak Rivers (figs. 7 and 8). An ERTS-1 (Earth Resources Technological Satellite) near-infrared image taken on March 31, 1973 , shows the icing overflow activity in the Sagavanirktok River basin. Water absorbs infrared radiation and is shown as black on the image (fig. 9a) in contrast to the white snow and ice. Broad overflow can be seen (fig. 9a) on the icings of the Echooka and Ivishak Rivers near the front of the Brooks Range and extending some distance downstream. An ERTS-1 scene of the same area on August 4,1973, shows remnants of ice on the Echooka, Shaviovik, and Ivishak Rivers (fig. 9b). The large icing on the Echooka River may not melt entirely from year to year (fig. 10). These icings are continuous for many miles, except along the lower reaches of the Sagavanirktok River. The amount of winter streamflow decreases downstream because water is stored in the icings. Except for unfrozen sand and gravel adjacent to the main channels of these rivers, most of the alluvial materials within the river systems are frozen. Thus, little or no ground-water discharge is available to maintain streamflow during the winter.

\section{BROOKS RANGE}

A large icing forms annually on the alluvial fan west of Galbraith Lake (figs. 11 and 12). Large icings also occur at wide, braided channel reaches of the upper Atigun River valley (figs. 11 and 13).

Icings inundate almost the entire active flood plain along braided channel reaches of the Dietrich River (fig. 14). Where the river channel is incised and the reach not braided, channel ice or only minor overflow icing occurs. The large icings on the Dietrich River seem to have their water source from the steep alluvial fans which have built out onto Dietrich River flood plain (figs. 15a and 15b). Open leads in the Dietrich River icings can be seen at the base of the alluvial fans where ground water is emerging (fig. 16). 


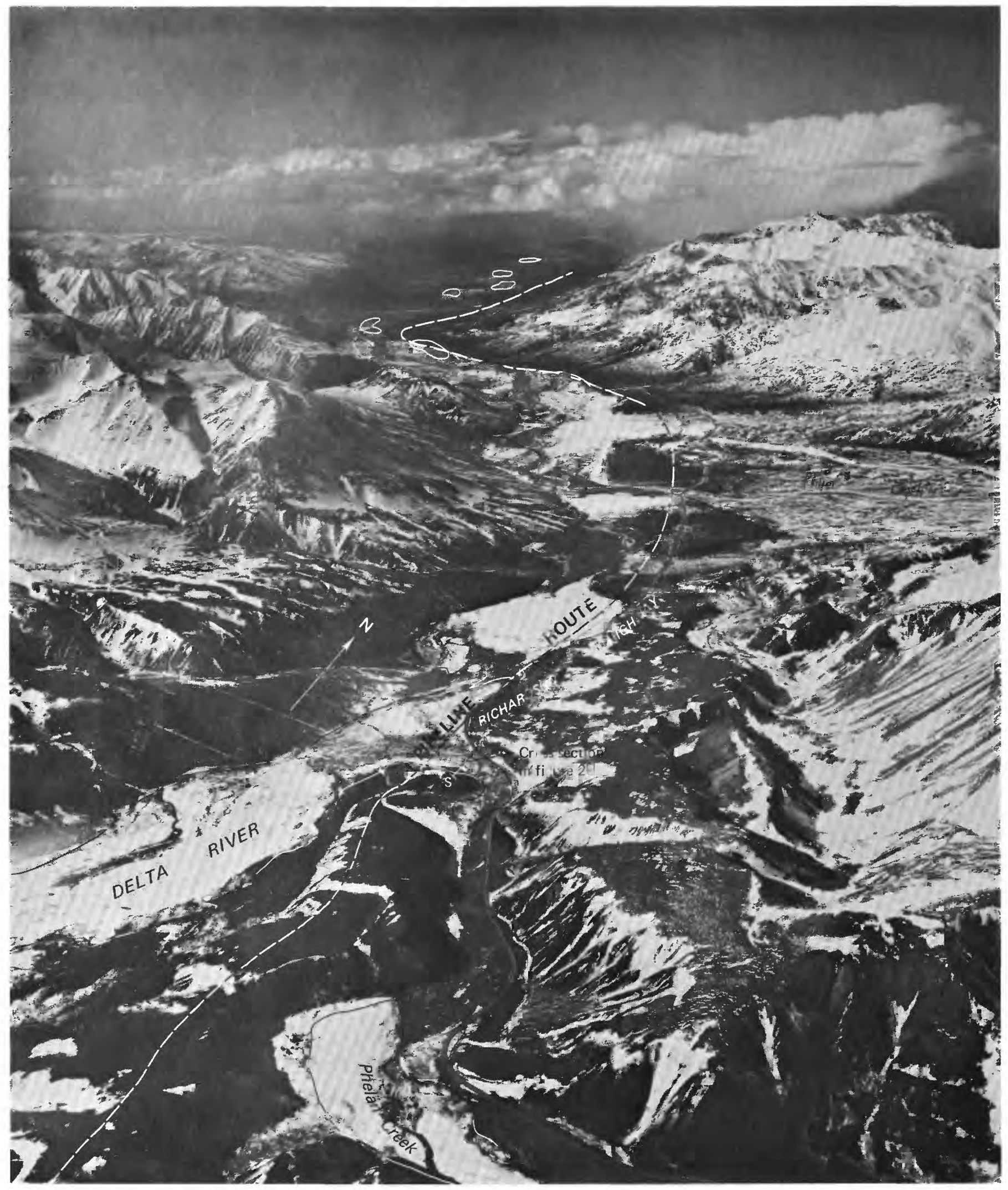

FIGURE 2.-Flood-plain icings on the Delta River and tributaries. View north along the pipeline route, May $22,1972$. 


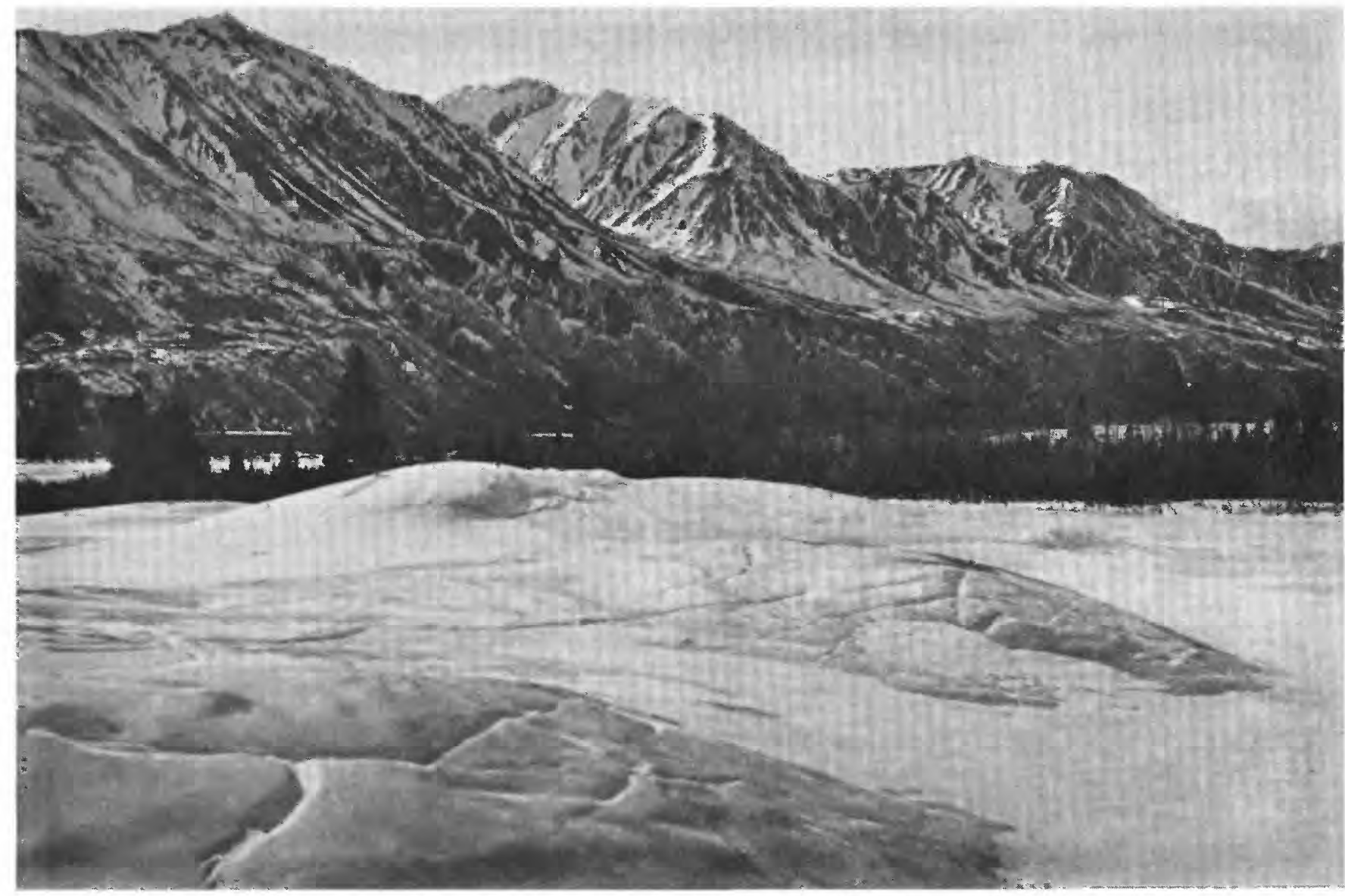

FIGURE 3.--Icing mounds on Trims Creek near pipeline crossing, Delta River valley, April 18, 1974.

The ice on the Middle Fork Koyukuk River (fig. 14) generally is confined to the main channel, and small icings form at the mouths of some tributary streams. A few small hillside icings form on the west flank of Sukakpak Mountain.

\section{INTERIOR BASINS AND HIGHLANDS}

From the Middle Fork Koyukuk River to the Fairbanks area, the pipeline route transects rather than parallels the streams, valleys, and ridges. Channel icings occur in the South Fork Koyukuk River, Prospect Creek, and other large streams crossed by the pipeline route (fig. 17). Icings from springs in Fish Creek have caused several local reroutings of winter trails. Icings do not occur on the Yukon River at the pipeline bridge crossing.

South of the Yukon River, narrow channel icings form on the small streams in the uplands (figs. 18 and 19). The source for these icings may be artesian water from bedrock drainage or from unfrozen ground above permafrost. The water emerges in small depressions or gullies that drain to the larger stream valleys.
Channel ice and minor overflow icing occurs on the major streams crossed by the pipeline between Fairbanks (fig. 20) and Big Delta (fig. 21). Icings form on many smaller streams draining the Yukon-Tanana Uplands. Thermal infrared imagery obtained in February 1974 shows water overflowing the icings in the Minton Creek area (fig. 22). In this imagery, the presence of water is indicated by the white areas that signify relatively higher temperatures. A large icing occurs along the pipeline route in the flats north of Shaw Creek (fig. 23). An open channel is usually maintained along the Tanana River at the planned pipeline crossing because relatively warm ground water is discharged along the south bank.

\section{ALASKA RANGE AND FOOTHILLS}

Small hillside and channel icings occur along the pipeline route between Donnelly Dome and Black Rapids (fig. 24). South of Black Rapids the pipeline route is in the active flood plain of the Delta River where extensive icings form annually (frontispiece; figs. 2, 25, and 26). Large icings form each winter at 


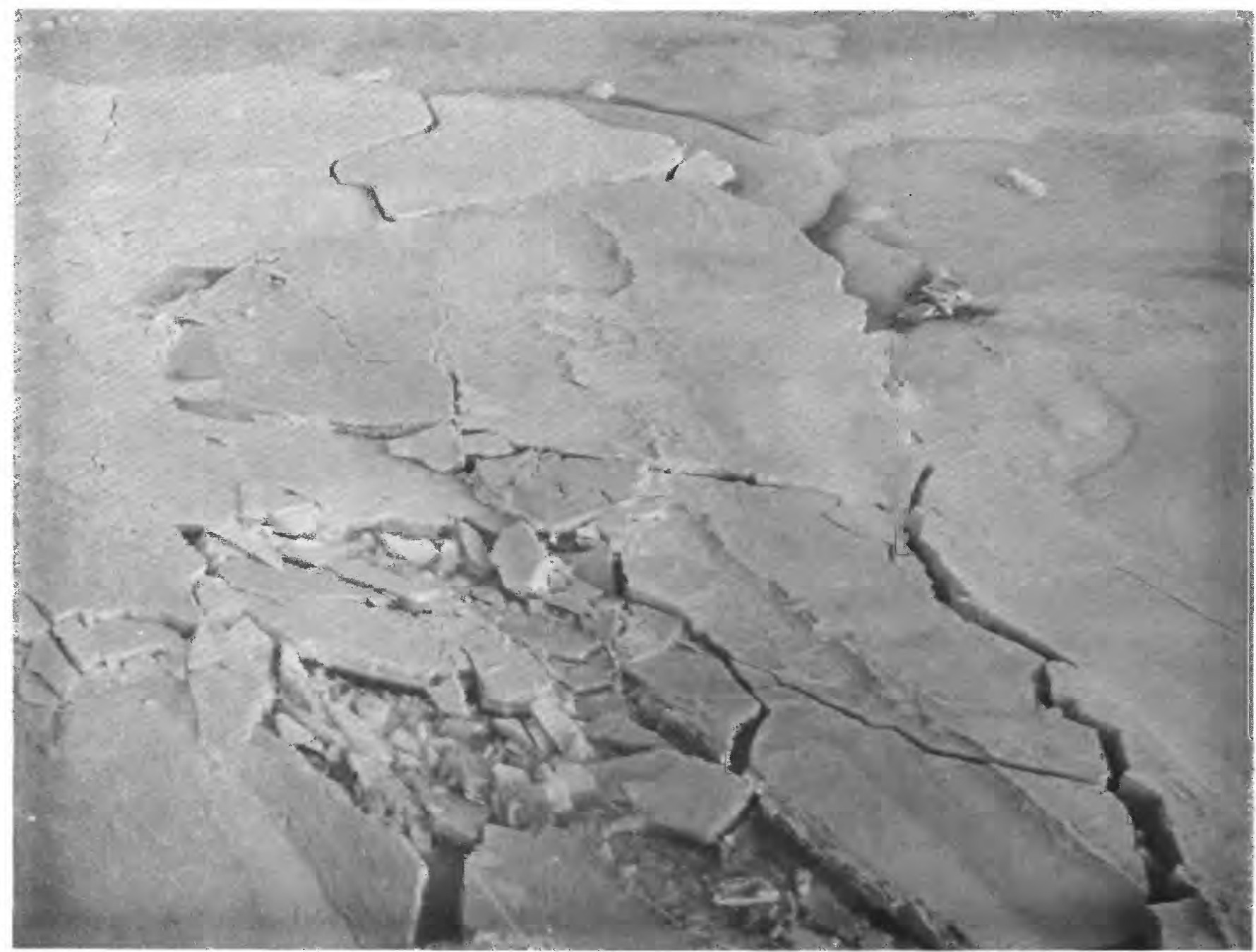

Figure 4.-Fractured icing mound on Dietrich River approximately 2 miles $(3.2 \mathrm{~km})$ downstream from confluence with Big Jim River, March 15, 1972. Explosive force scattered ice blocks for tens of feet.

Castner Creek, lower Miller Creek, Miller Creek, Phelan Creek, and McCallum Creek (fig. 27), streams crossed by the pipeline.

Borings were made through the Phelan Creek icing at the confluence of the Delta River and Phelan Creek on April 27, 1972 (fig. 28). The ice averaged about 5 feet $(1.5 \mathrm{~m})$ thick, and of 31 holes drilled along a 1,000foot (305-m) section, only 1 reached water in a channel under the ice. In the remainder of the holes, ice was resting directly on sand and gravel channel deposits.

Icings in Phelan Creek and the Delta River are subject to minor flooding by water released from Fielding Lake when ice blocking the outlet of the lake is breached (Post and Mayo, 1971). Such floods usually occur annually in late winter and consist of water and slush flowing over the icings. Some of these outbursts have inundated the highway.
Near Isabel Pass a large icing forms annually on Gunn Creek at the Richardson Highway bridge (fig. 29).

\section{COPPER RIVER BASIN}

The main icings along the pipeline route through the Copper River basin are due to hillside springs and seeps, such as those along the Richardson Highway near Paxson Lake (fig. 30). Areas of stream icing occur along Spring Creek near Roundtop Mountain and along Sourdough Creek near the Gulkana River. Major icings have occurred at the Klutina River (fig. 31) and have inundated part of the town of Copper Center (U.S. Army Corps of Engineers, 1967). Large icings also form on the Tonsina River and Squirrel Creek below the pipeline crossing and have been reported on the Tazlina River (Williams, 1953). 


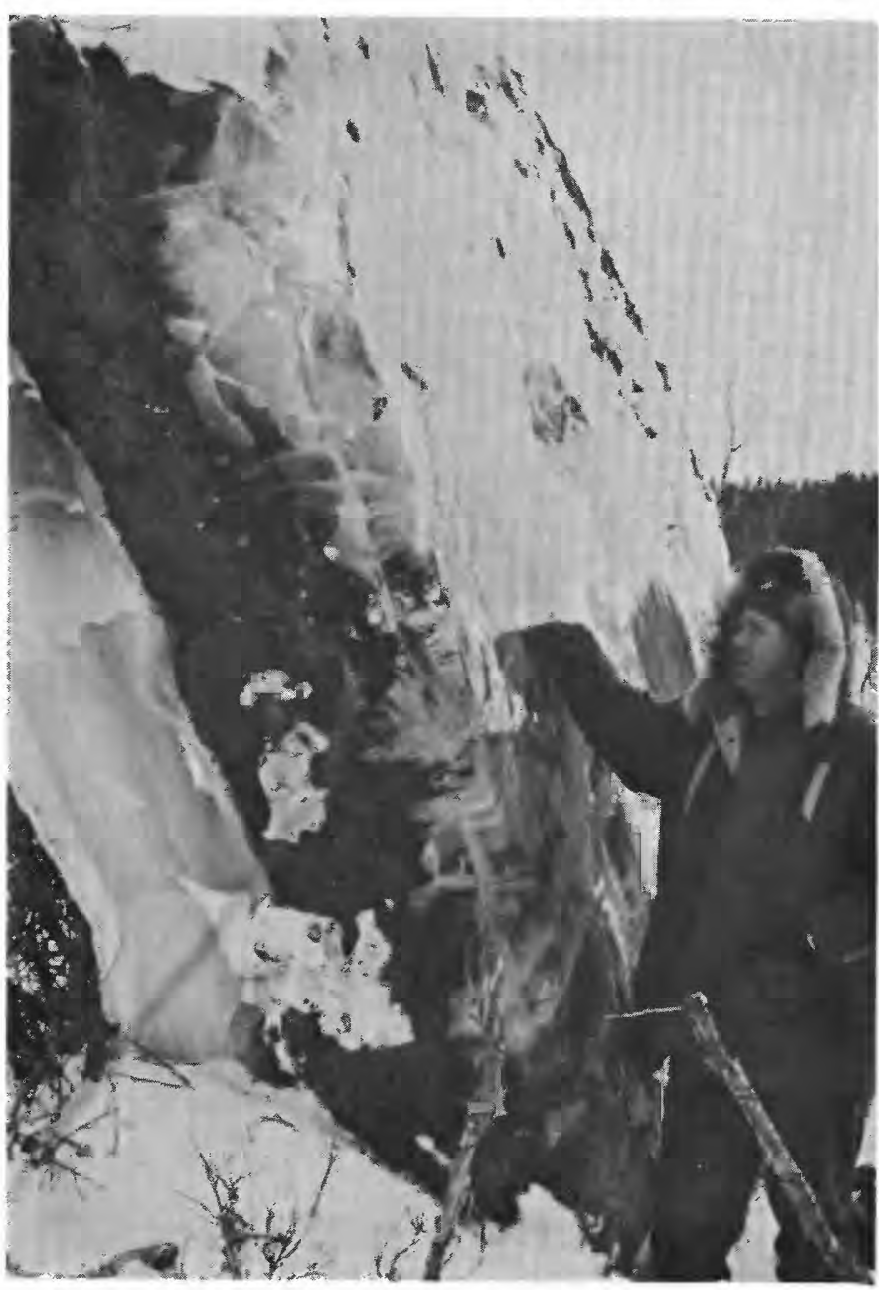

FIgURE 5.-Upheaved ice and soil block from exploded hillside icing mound north of Old Man camp in Fish Creek valley, March 21, 1974.

\section{CHUGACH MOUNTAINS}

Streams in this section generally have high gradients, narrow valley bottoms, and few braided channel reaches except for the upper part of the Tsina and the lower part of the Lowe Rivers (fig. 31). Icings are generally small, discontinuous, and restricted to short braided channel reaches or hillside areas.

Hillside icings formed by seeps and springs in the Little Tonsina valley (fig. 32) have been particularly bothersome requiring repeated culvert maintenance by the Alaska Department of Highways. The occurrence of icings in the Chugach Mountains indicates that icings are not unique to the northern parts of Alaska. They are scattered along the entire length of the trans-Alaska pipeline route.

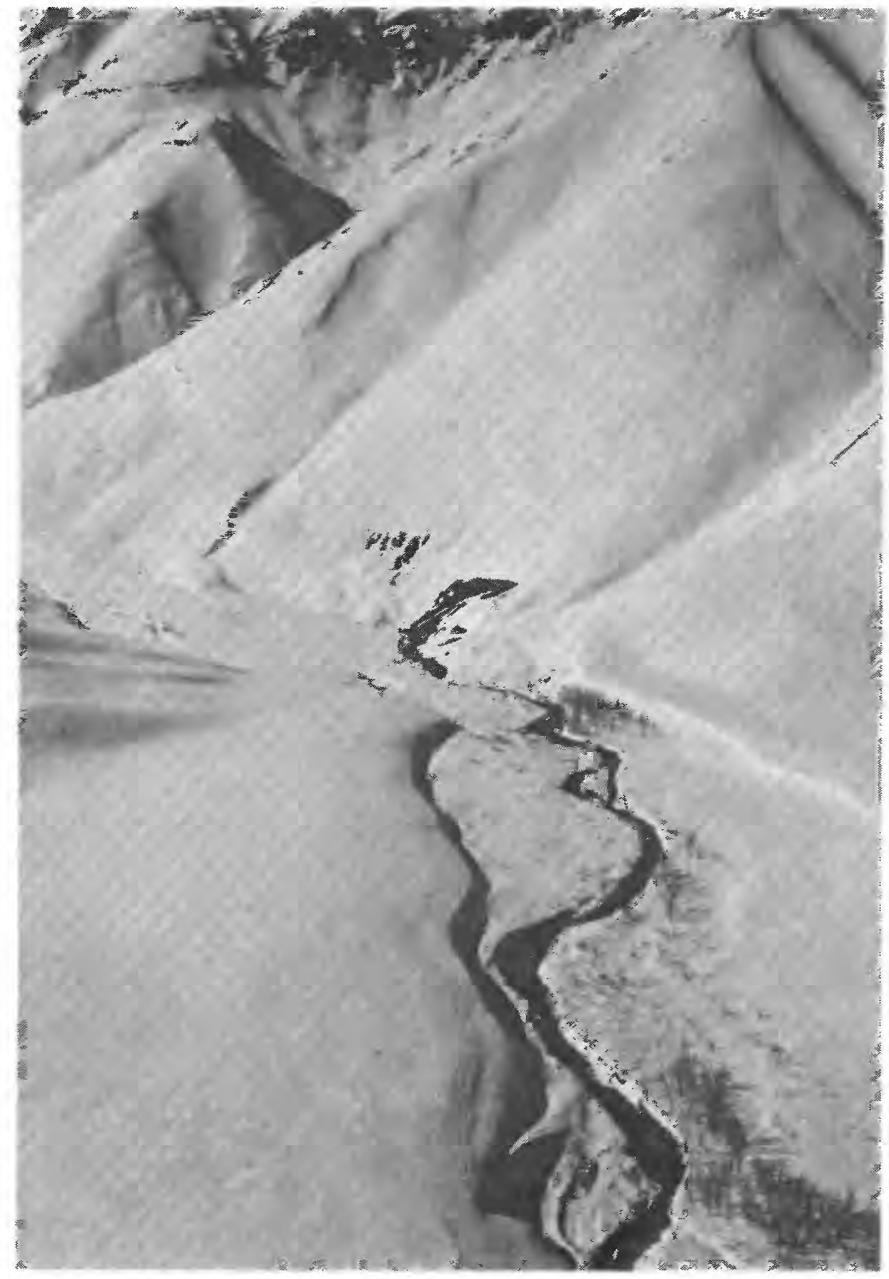

Figure 6.-Hillside spring in Brooks Range near Ivishak River, May 11, 1973. Balsam poplar are $30-40$ feet $(10-12 \mathrm{~m})$ tall.

\section{POTENTIAL PROBLEMS AND HAZARDS OF ICINGS}

The engineering works of man in a naturally icingprone area could be factors in initiating icings (Chekotillo and others, 1960). The building of structures such as pipelines and roads involves (a) the passage of heavy vehicles and equipment over the terrain, (b) placement of fill material, and (c) excavations at cuts and trenches. Vehicular traffic can physically break up and (or) compact the insulating vegetation mat and surface peat deposits, either of which could cause a greater depth of both freezing in winter and thawing in summer. The placement of fill material compacts the natural surficial materials and changes 

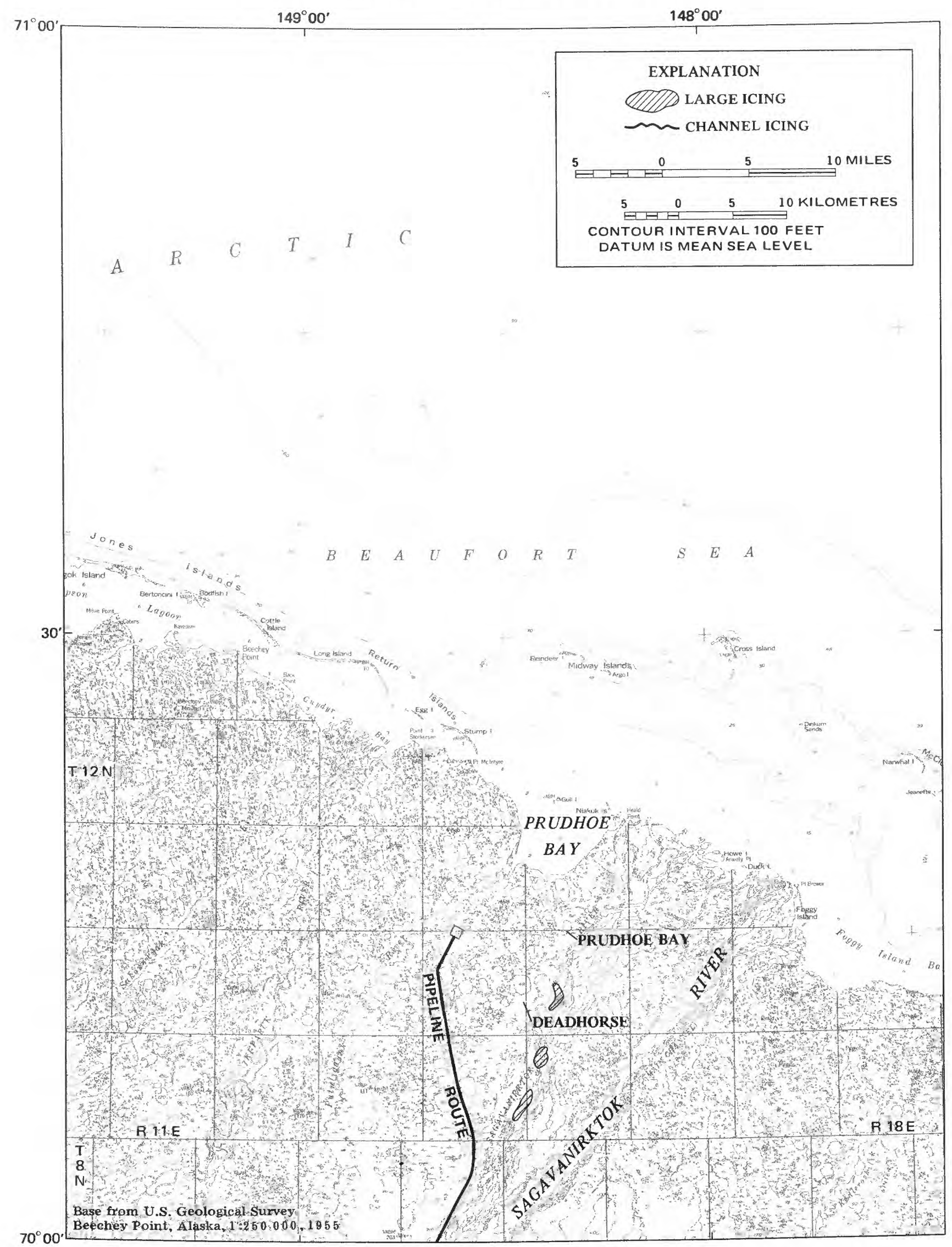

FIGURE 7.-Distribution of icings along the trans-Alaska pipeline route in the Beechey Point quadrangle. 


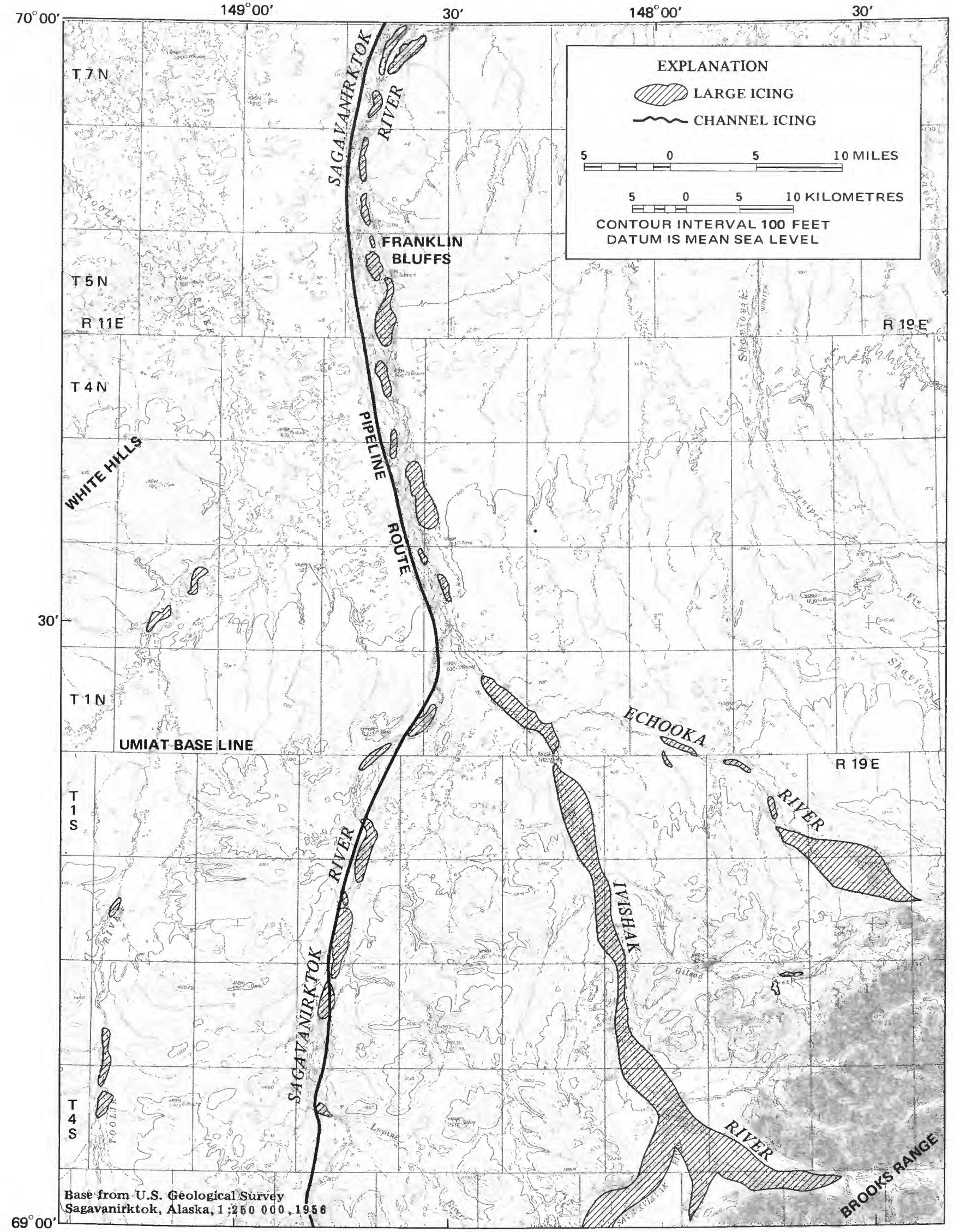

Figure 8.-Distribution of icings along the trans-Alaska pipeline route in the Sagavanirktok quadrangle. 
the albedo and snow cover, thereby affecting the thermal regime. In addition, a very thick fill might act as an insulator, causing aggradation of permafrost into the fill embankment (Ferrians and others, 1969). This permafrost dam constitutes a barrier to ground-water movement. Road and borrow-pit cuts (fig. 32) and trenches for the pipeline could intercept shallow ground water. In permafrost areas, a common result of deeper winter freezing, greater summer thawing, growth of frost dams on hillsides, and exposure of ground-water flow zones is a greater than normal flow of ground water to the surface (Eager and Pryor, 1945) with consequent growth of icings.

Ice inundation is a special winter flooding problem. During the winter of 1964-65, the village of Copper Center was extensively flooded by icings from the Klutina River (U.S. Army Corps of Engineers, 1967). During spring runoff, melt-water channels cut through icings if the breakup is gradual. If breakup occurs rapidly, high water flows over the icings and may cause flooding and embankment washouts.

The icing at McCallum Creek in the Alaska Range illustrates the problems caused by bridge and channel structures. This icing usually builds to a thickness of about 20 feet $(6 \mathrm{~m})$ or greater each year at the Richardson Highway bridge because the channel is constricted by wingwall dikes and the bridge abutments. The early spring runoff flows on top of this icing and has damaged the road embankment and dikes.

Operation of the trans-Alaska pipeline where buried may be expected to cause two special types of icing problems. First, the thawed cylinder along the pipeline may serve as a conduit for ground-water flow. If ground water flows along this thawed zone, the water will be discharged to the surface at each low point. New icings may be formed where this ground water reaches the surface. Second, heat lost from the pipe buried in the streambed beneath icings will eliminate or reduce the thickness of any icing above the pipe. High water from rainstorms, ice and snowmelt, and outburst flooding may be concentrated over the buried pipe by channels in the icings. Hence, unusual and severe scour conditions could result at these locations.

\section{REFERENCES}

Carey, K. L., 1970, Icing occurrence, control and prevention-An annotated bibliography: U.S. Army Corps of Engineers Cold Regions Research and Eng. Lab. in cooperation with State of Alaska, Dept. of Highways and U.S. Dept. of Transp., Federal Highway Adm., Spec. Rept. 151, 60 p.

1973, Icings developed from surface water and ground water: U.S. Army Corps of Engineers Cold Regions Research and Eng. Lab.,Cold Regions Science and Eng. Mon. III-D3, 65 p.

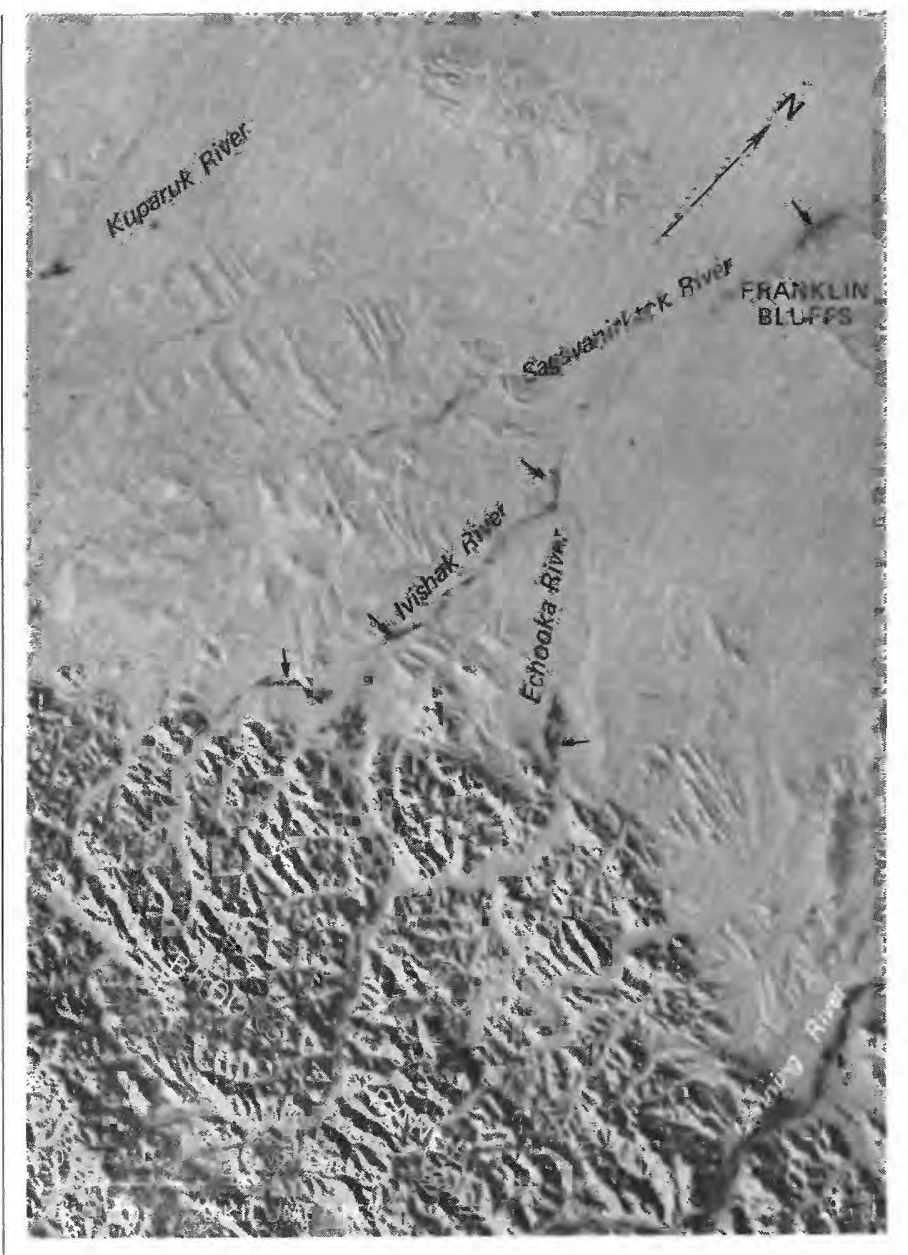

FIGURE 9.-ERTS-1 images of the Sagavanirktok River basin. A, ERTS-1 image taken on March 31, 1973 showing water surfaces (arrows) in icing areas (scene No. 12511-21123, band 7).

Chekotillo, A. M., Tsvid, A. A., and Makarov, V. N., 1960, Icings in the USSR and their control [Naledi na territorii SSSR i bor'ba s nimi]: Natl. Tech. Inf. Service AD 711 933, 207 p. [1970].

Eager, W. L., and Pryor. W. T., 1945, Ice formation on the Alaska Highway: Public Roads, v. 24, no, 3, p. 55-74, 82.

Ferrians, O. J., Jr., Kachadoorian, Reuben, and Greene, G. W., 1969, Permafrost and related engineering problems in Alaska: U.S. Geol. Survey Prof. Paper 678, 37 p.

Kane, D. L., Carlson, R. F., and Bowers, C. E., 1973, Groundwater pore pressures adjacent to subarctic streams in Permafrost, North American Contribution, Internat. Conf., 2d, Yakutsk, [Siberia] USSR, 1973: Nat. Acad. Sci., p. 453-462.

Post, Austin, and Mayo, L. R., 1971, Glacier dammed lakes and outburst floods in Alaska: U.S. Geol. Survey Hydrol. Inv. Atlas HA-455.

U.S. Army Corps of Engineers, 1967, Detailed project report on flood control, Copper Center, Alaska: U.S. Army Corps of Engineers, Alaska District, $18 \mathrm{p}$.

Williams, J. R., 1953, Observations on river-ice conditions near highway bridges in Alaska, winter 1949-1950: U.S. Geol. Survey in cooperation with Engineer Intelligence Div., Office, Chief of Engineers, U.S. Army Eng. notes 30, 40 p. 


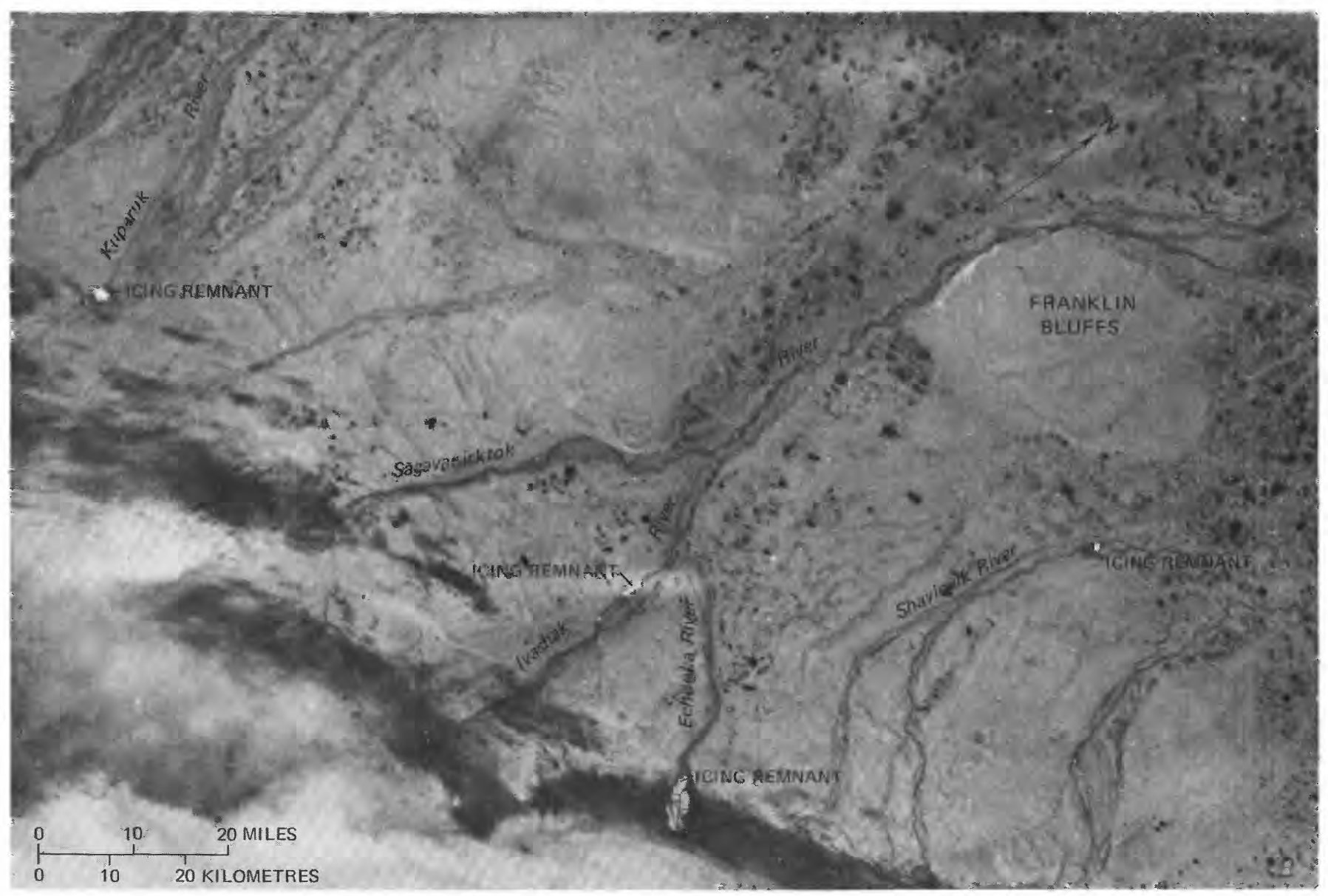

$B$, ERTS-1 image of the same area in $A$, taken on August 4, 1973, showing icing remnants on Echooka, Ivishak, and Shaviovik Rivers (scene No. 1377-21112, band 6). 


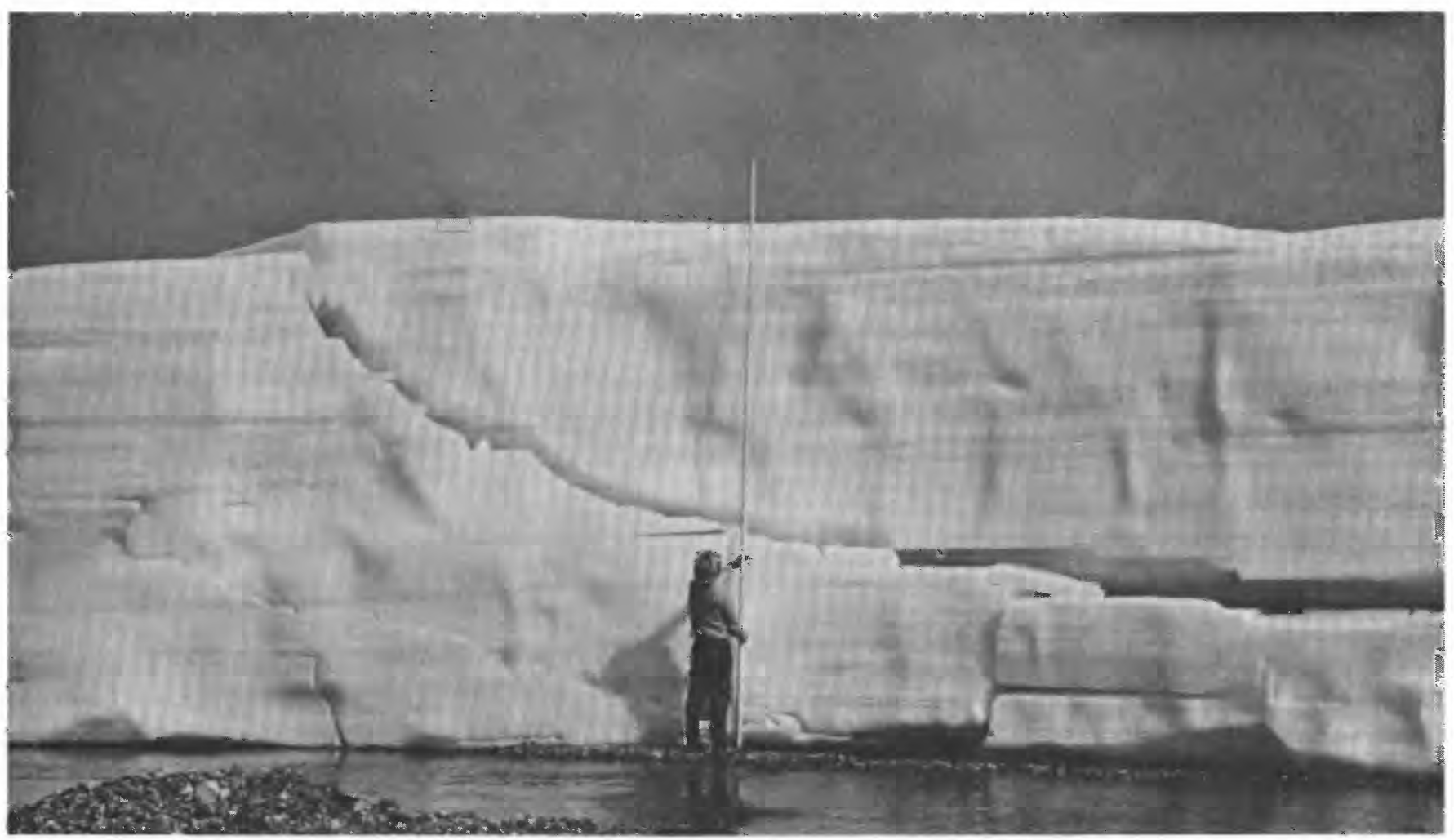

FIGURE 10.-Echooka River icing about 16 feet $(5 \mathrm{~m})$ thick, July 11, 1972. Layering in ice shows that numerous overflows make up the icing. 


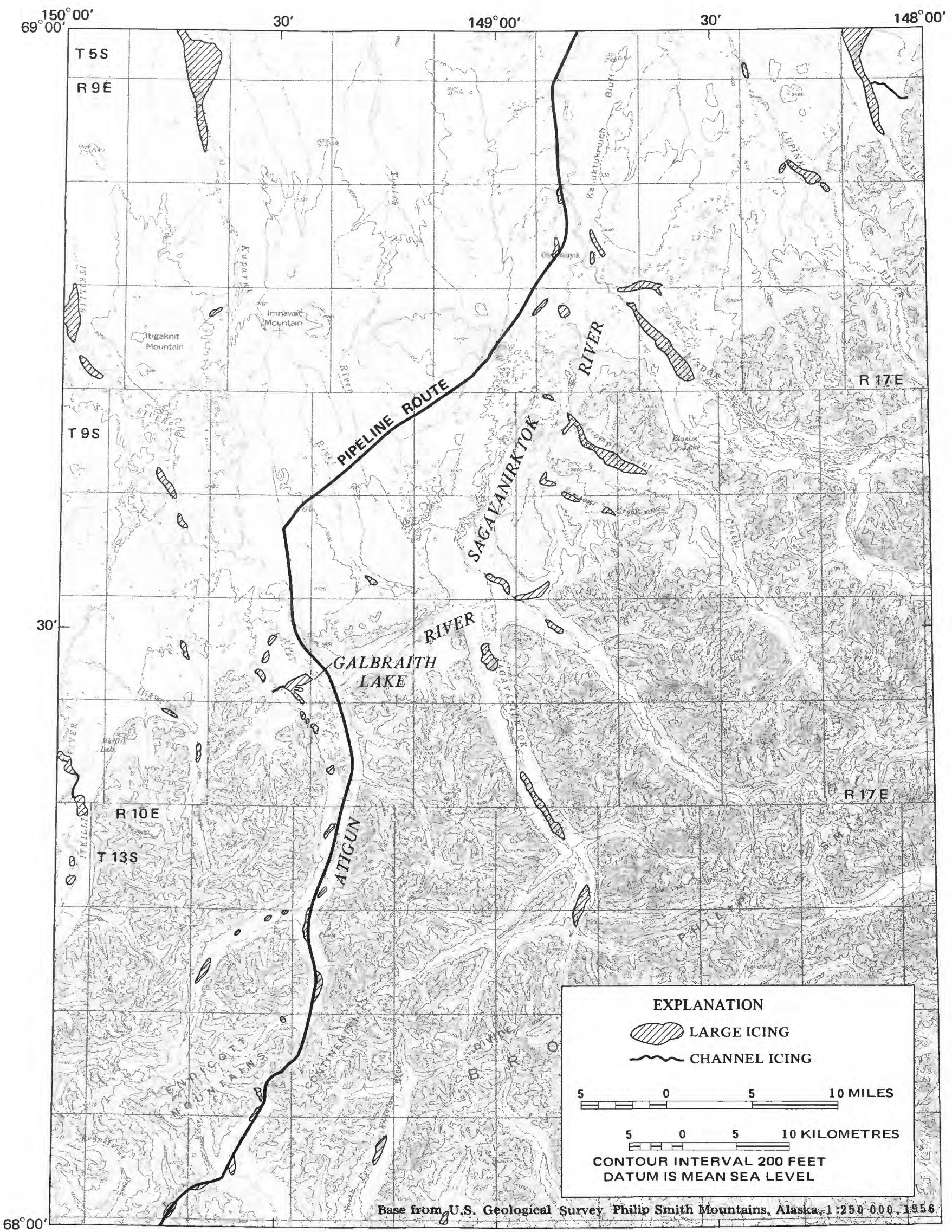

FIgURE 11.-Distribution of icings along the trans-Alaska pipeline route in the Philip Smith Mountains quadrangle. 


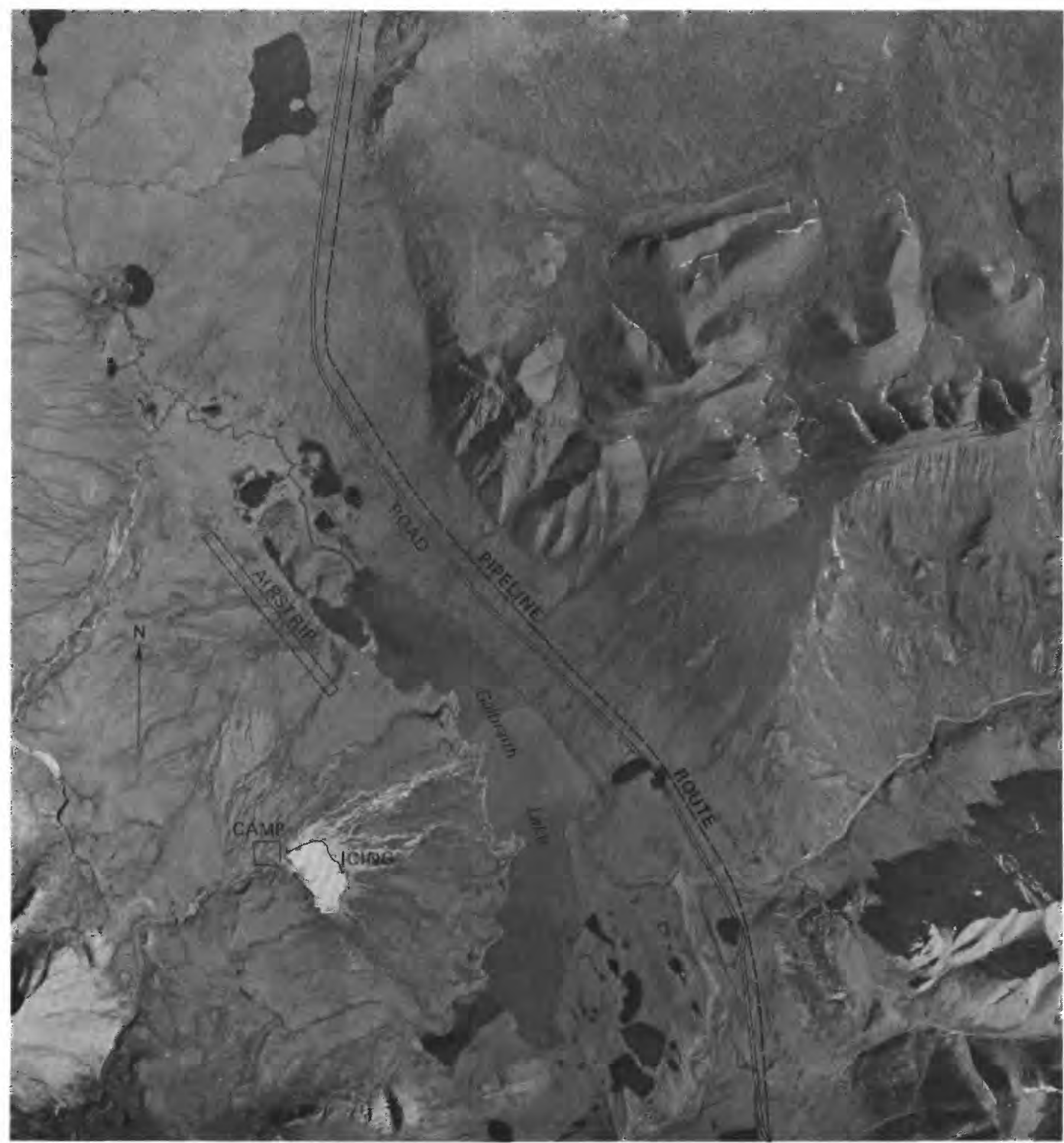

Figure 12.-Icing on alluvial fan at Galbraith Lake, July 21, 1956. (Approximate scale: 1 in. $=4,000 \mathrm{ft}$ or $1 \mathrm{~cm}=480 \mathrm{~m}$.) 


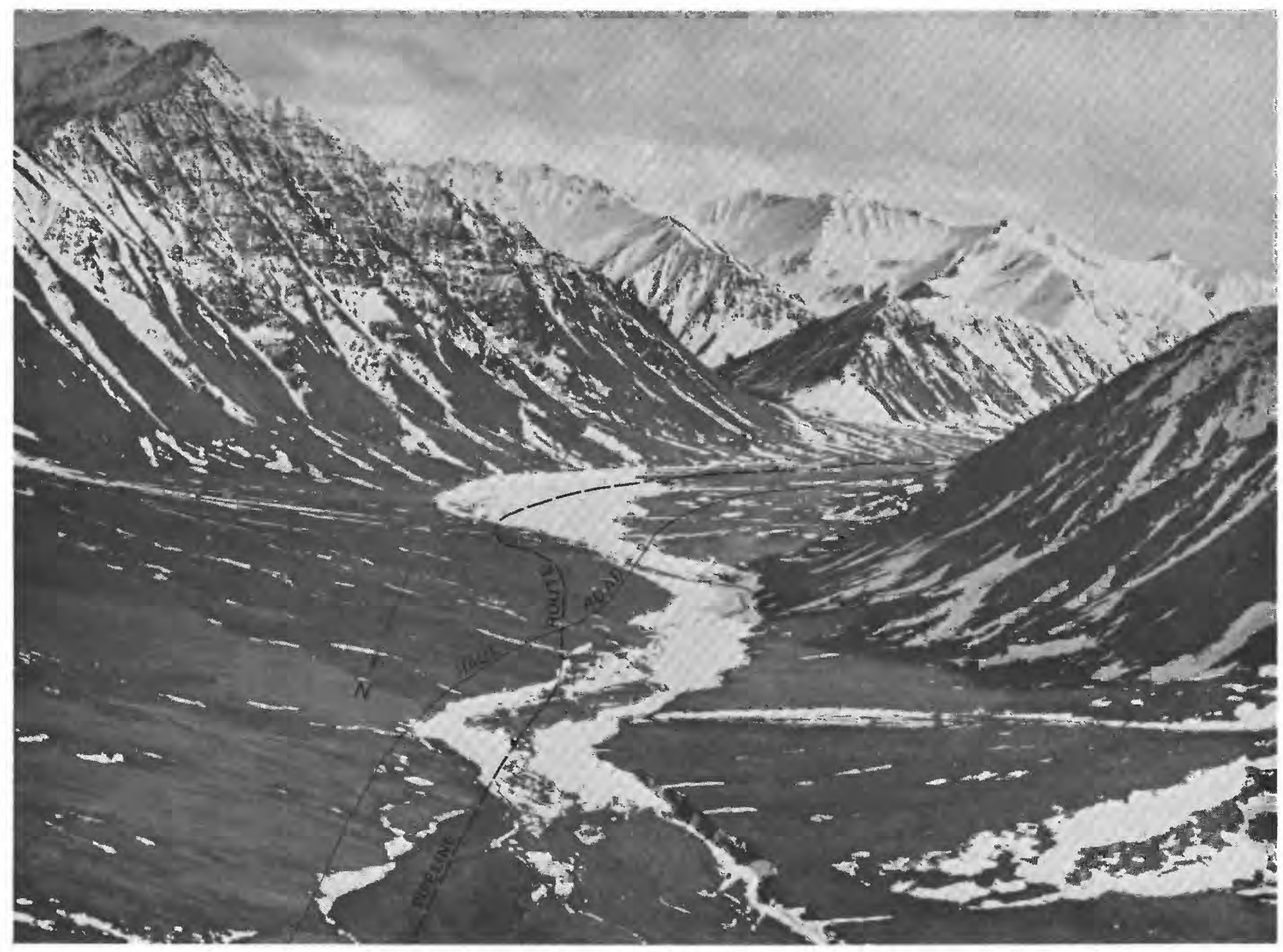

FIGURE 13.-Icings in braided reaches of Atigun River, May 29, 1973. 


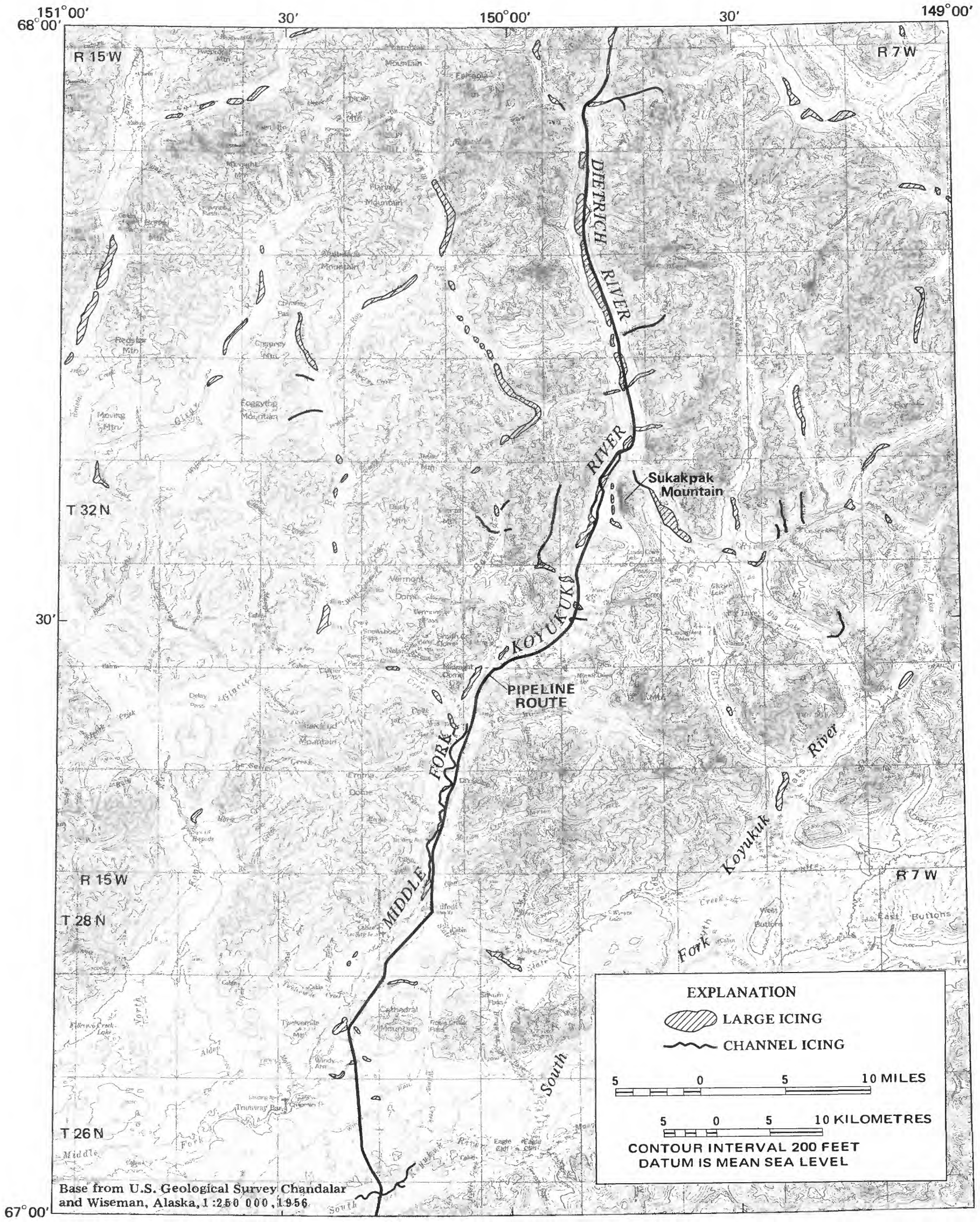

FigURE 14.-Distribution of icings along the trans-Alaska pipeline route in the Chandalar and Wiseman quadrangles. 

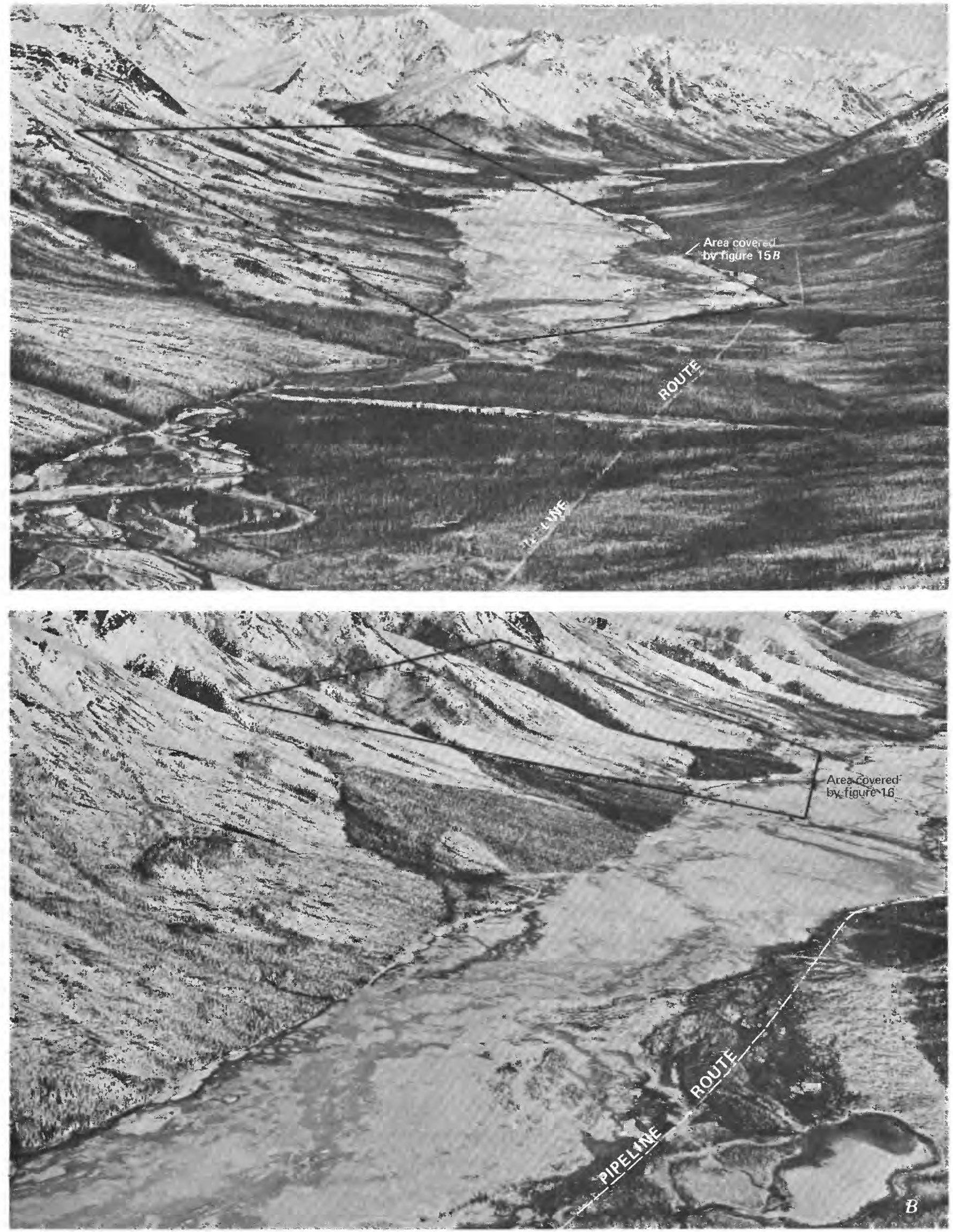

FIGURE 15.-Icings on the Dietrich River flood plain. $\quad$ A, Icing in Dietrich River valley upstream from Snowden Creek, May 1, 1974. $B$, Closeup view of part of icing shown in $A$. 


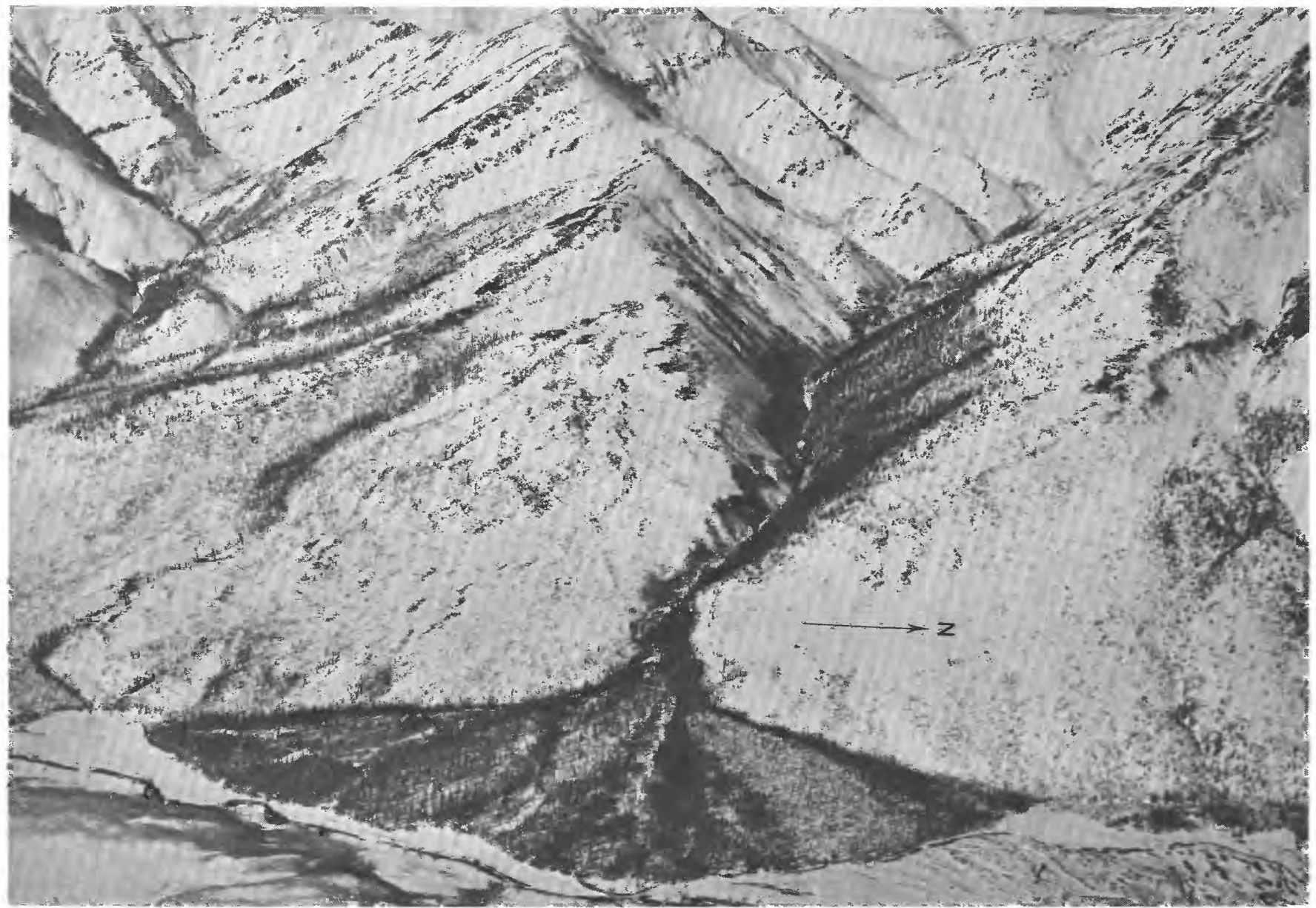

Figure 16.-Alluvial fan in Dietrich River valley upstream from Snowden Creek, May 1, 1974. Open leads at toe of fan are source of water for downstream icings. 


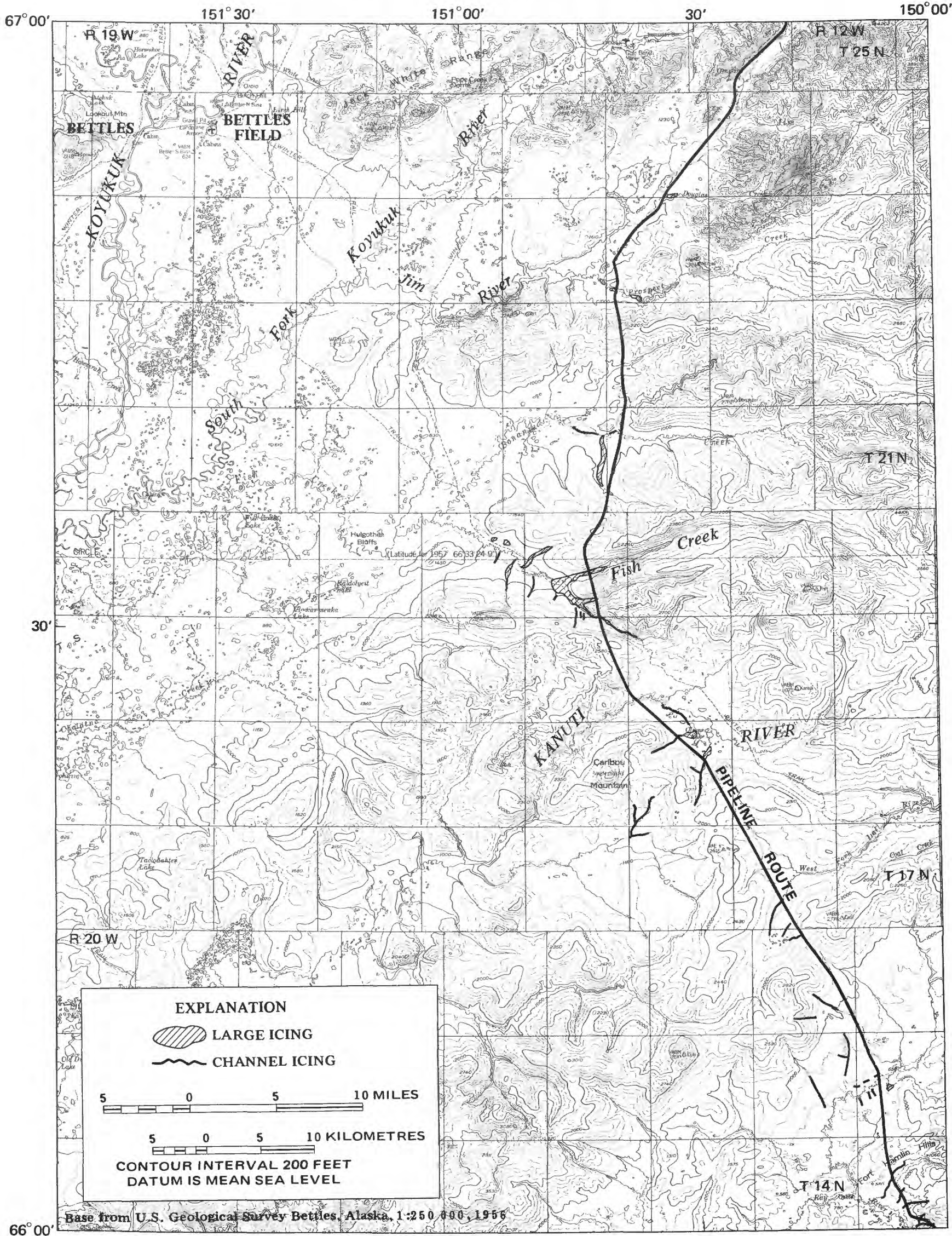

FIGURE 17.-Distribution of icings along the trans-Alaska pipeline route in the Bettles quadrangle. 


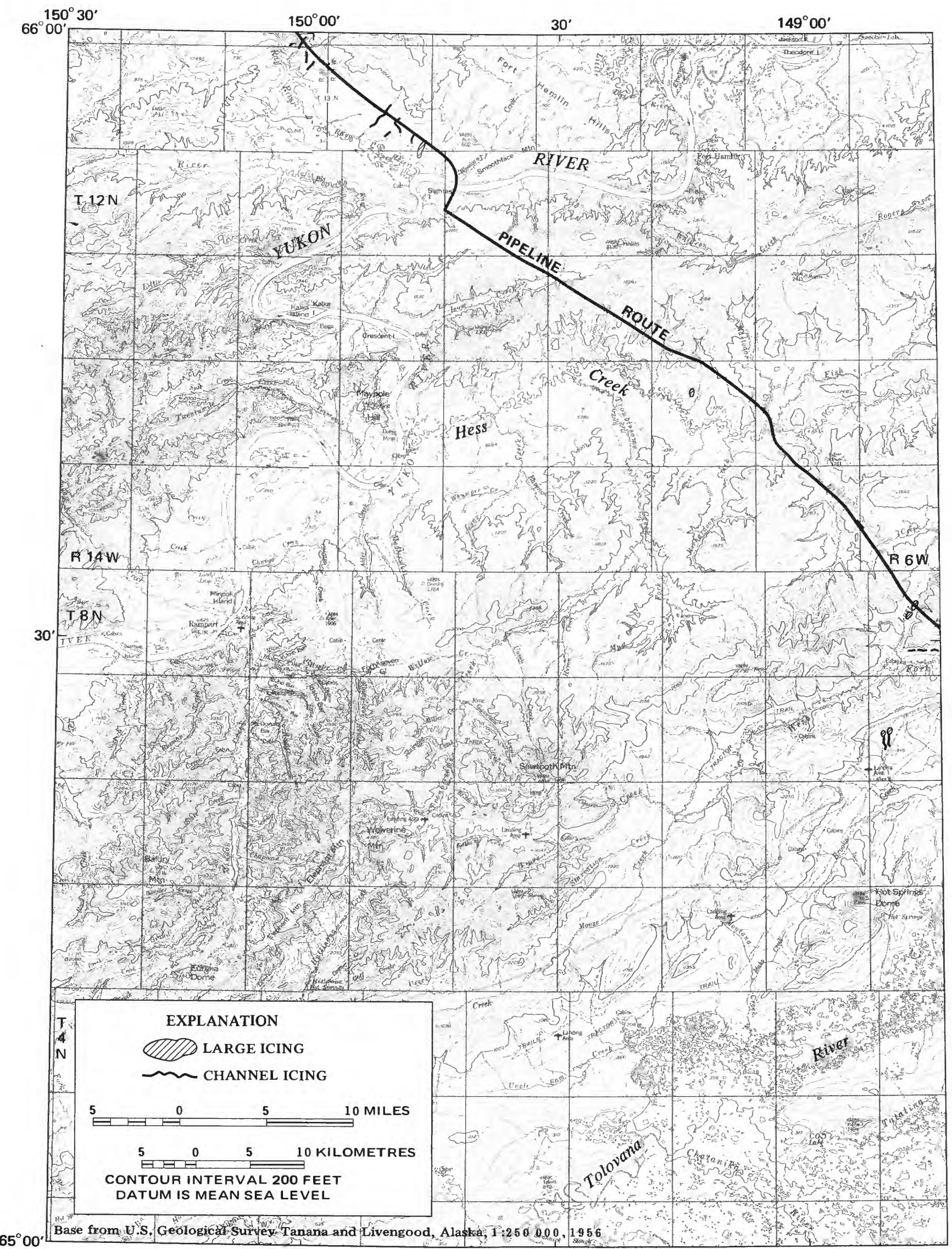

FIGURE 18.-Distribution of icings along the trans-Alaska pipeline route in the Tanana and Livengood quadrangles. 


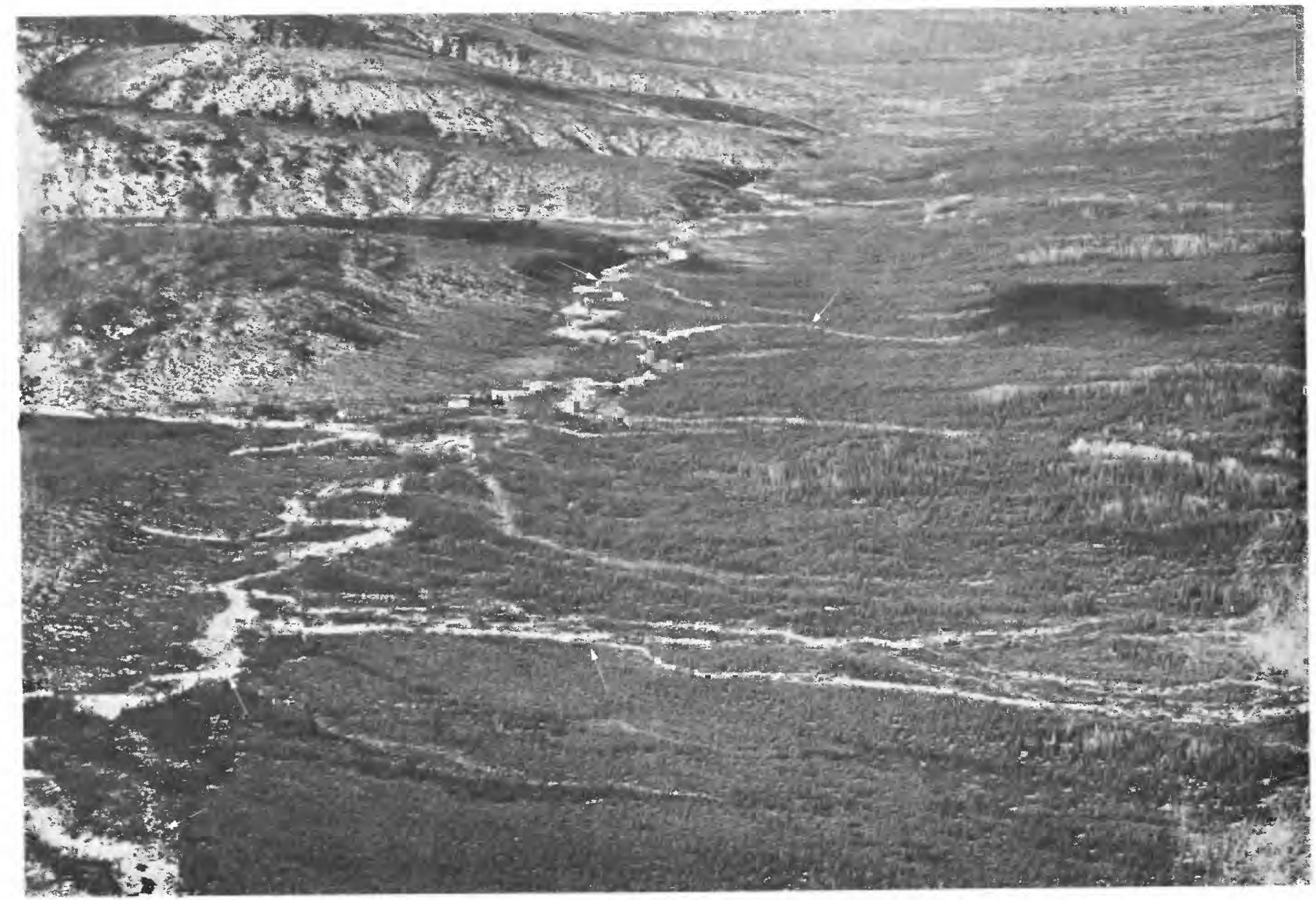

FIGURE 19.-Channel and hillside icings along Aggie Creek in Yukon-Tanana Uplands north of Fairbanks, May $23,1973$. 


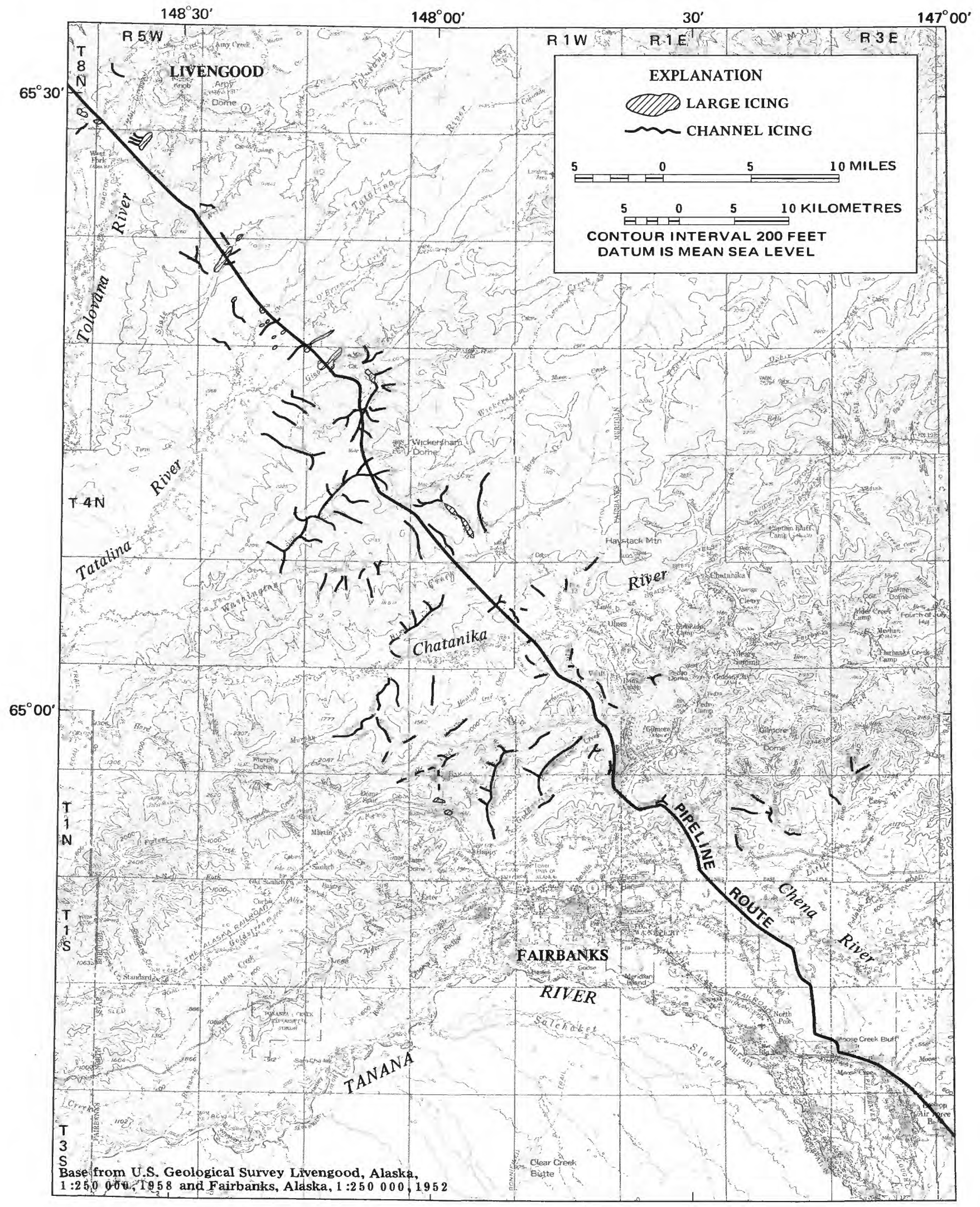

FIGURE 20.-Distribution of icings along the trans-Alaska pipeline route in the Livengood and Fairbanks quadrangles. 


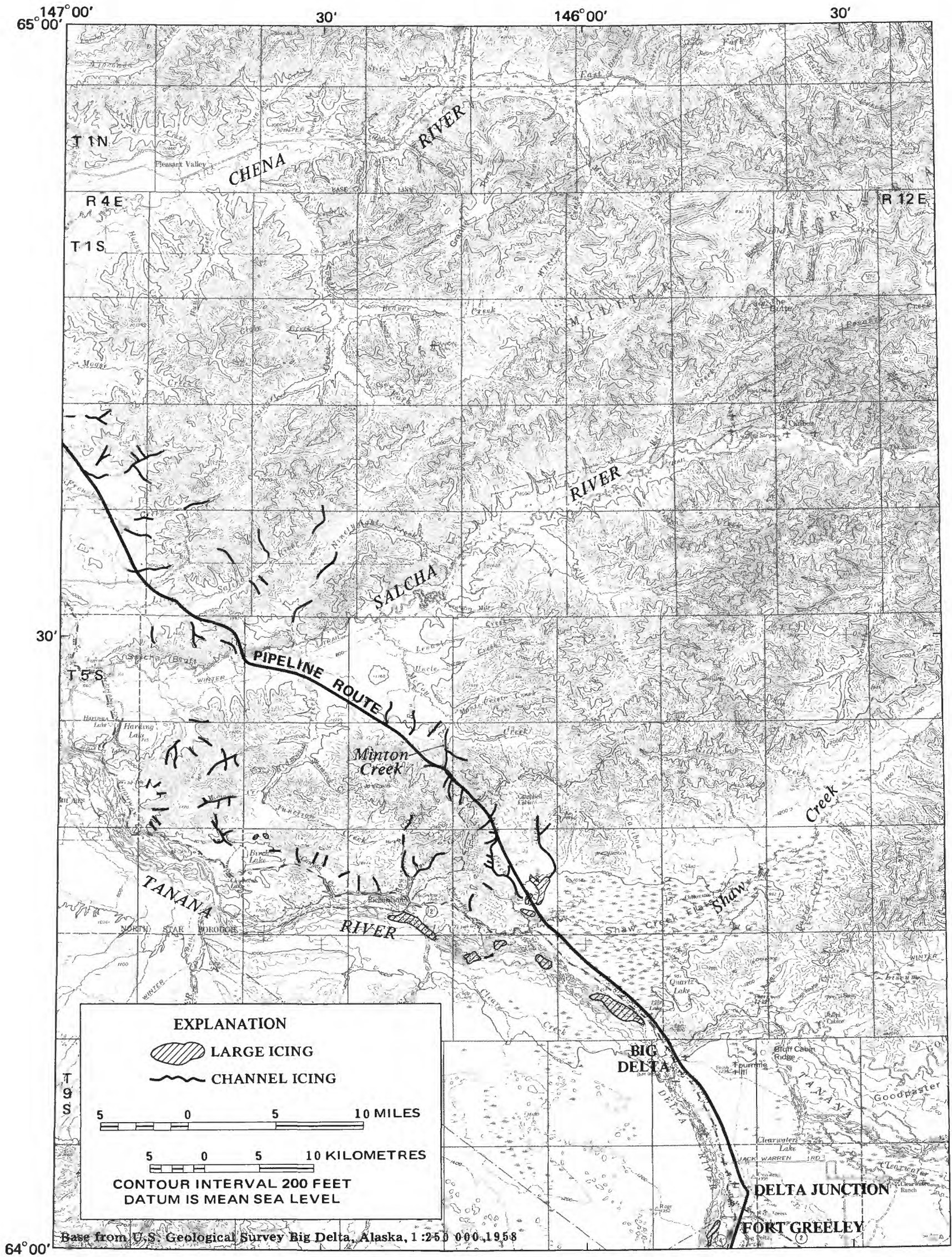

FIGURE 21.-Distribution of icings along the trans-Alaska pipeline route in the Big Delta quadrangle. 


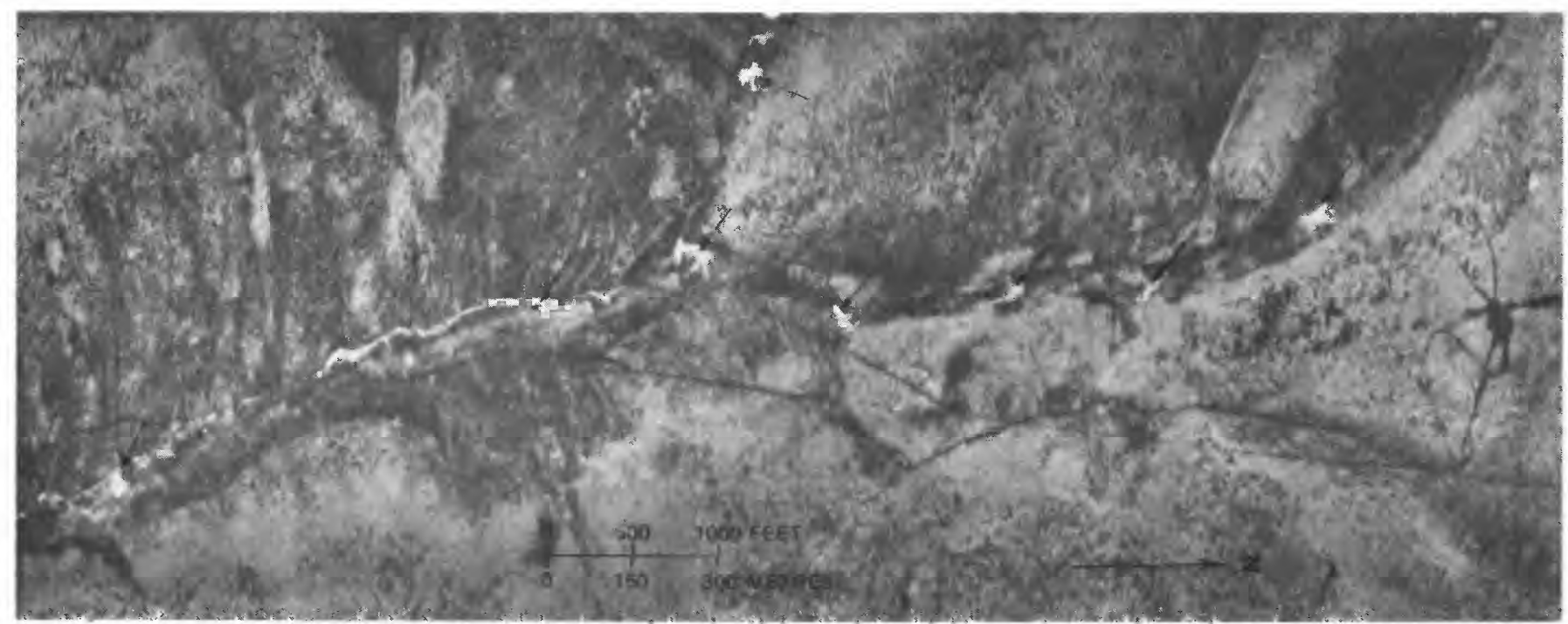

Figure 22.-Thermal infrared image of icings along Minton Creek, February 4, 1974. Water surfaces (arrows) contrast with snow and vegetation background.

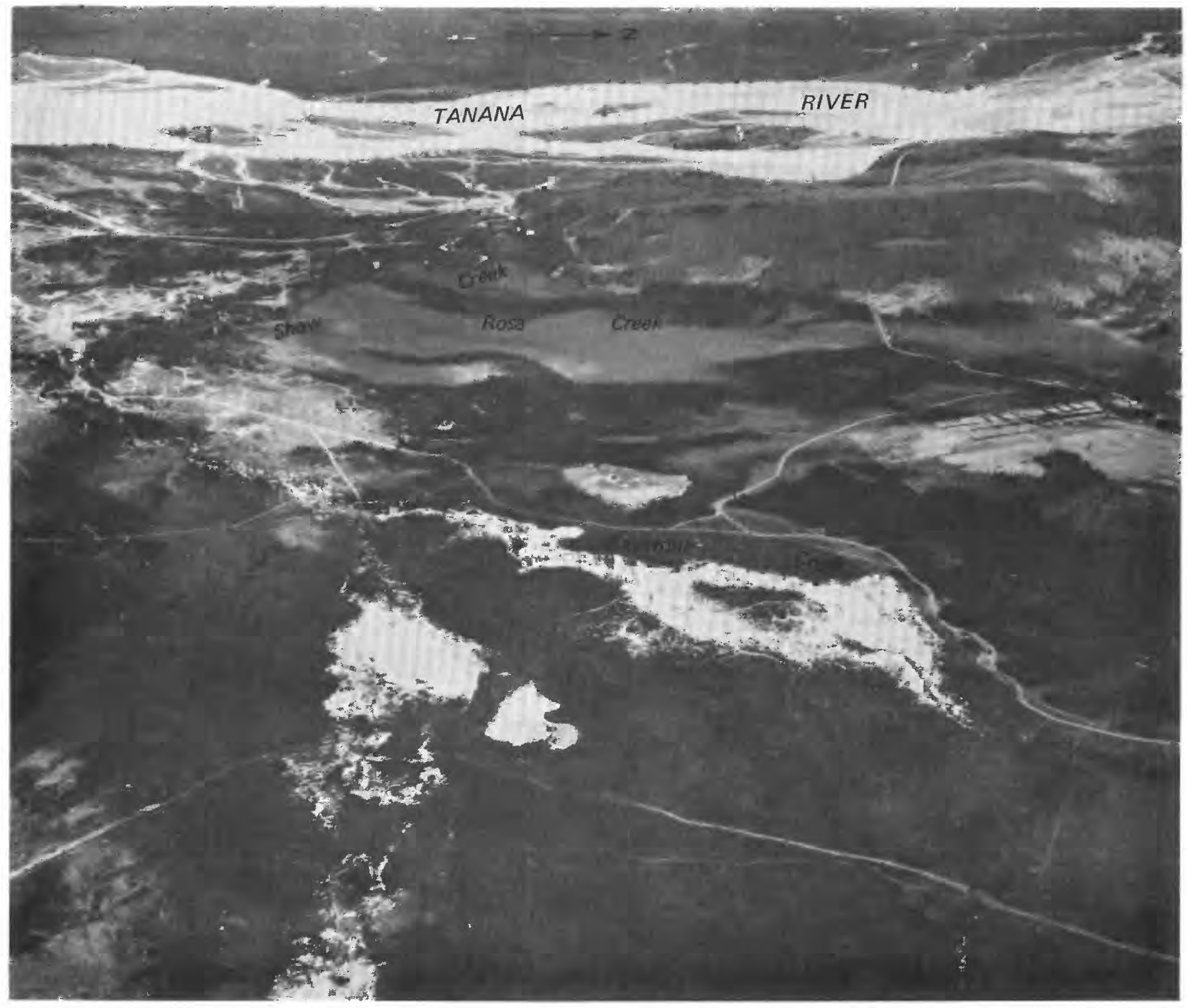

Figure 23.-Icings in flats north of Shaw Creek, May 22, 1972. 


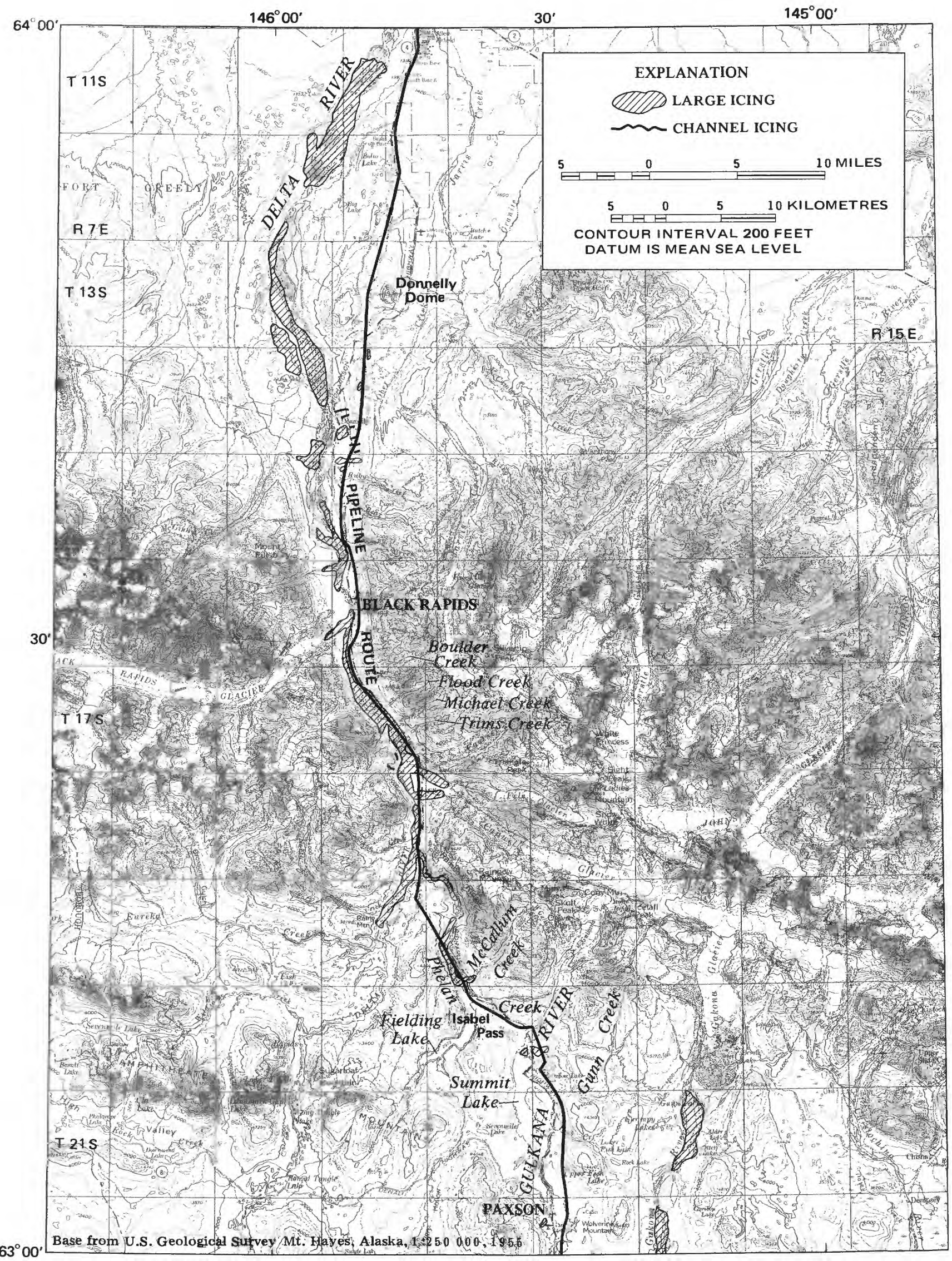

FIGURE 24.-Distribution of icings along the trans-Alaska pipeline route in the Mt. Hayes quadrangle. 


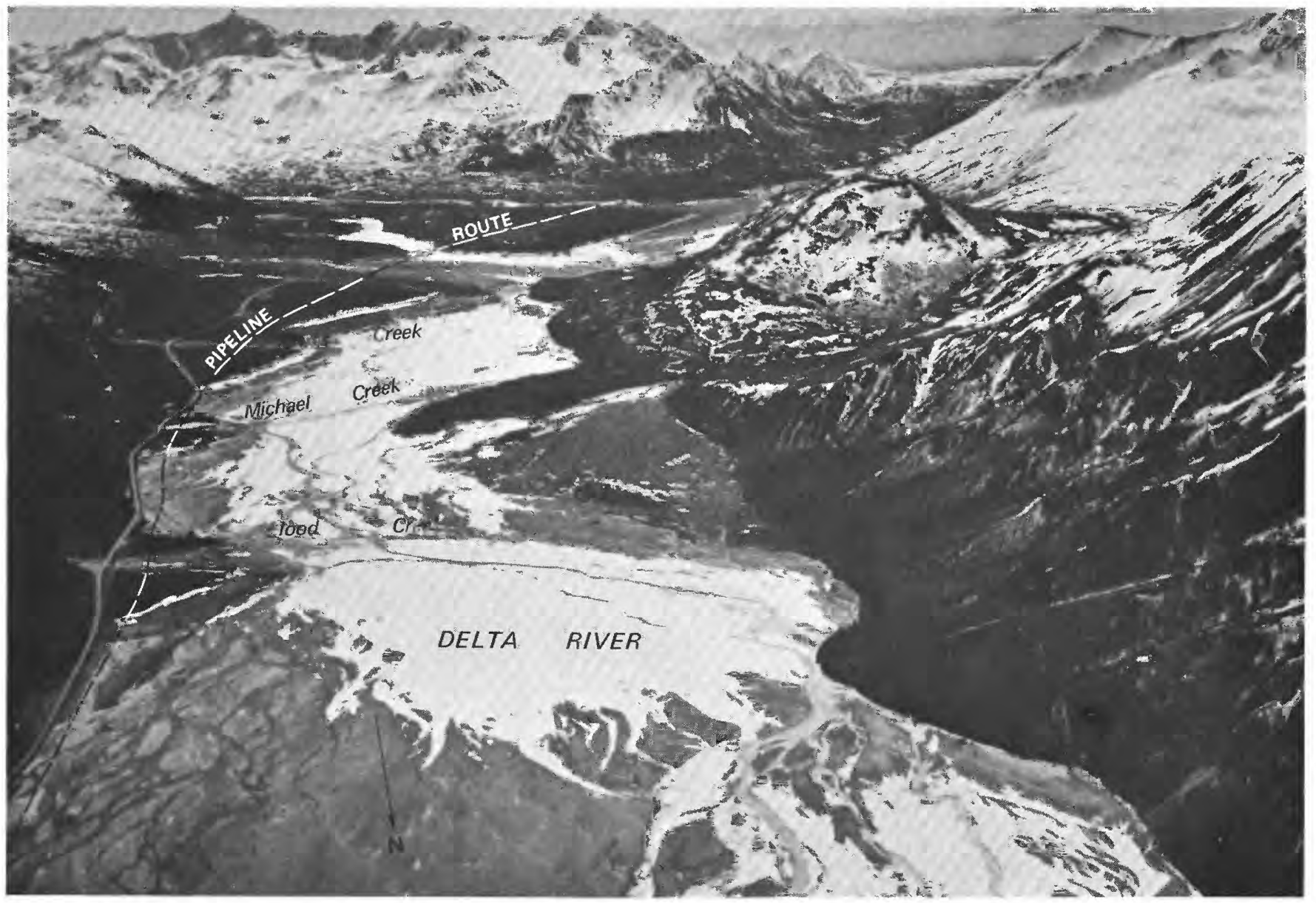

FIGURE 25.-Flood-plain icings along Delta River. Alluvial fans of Flood, Michael, and Trims Creeks in left foreground. View south (upstream) on May 29, 1973.

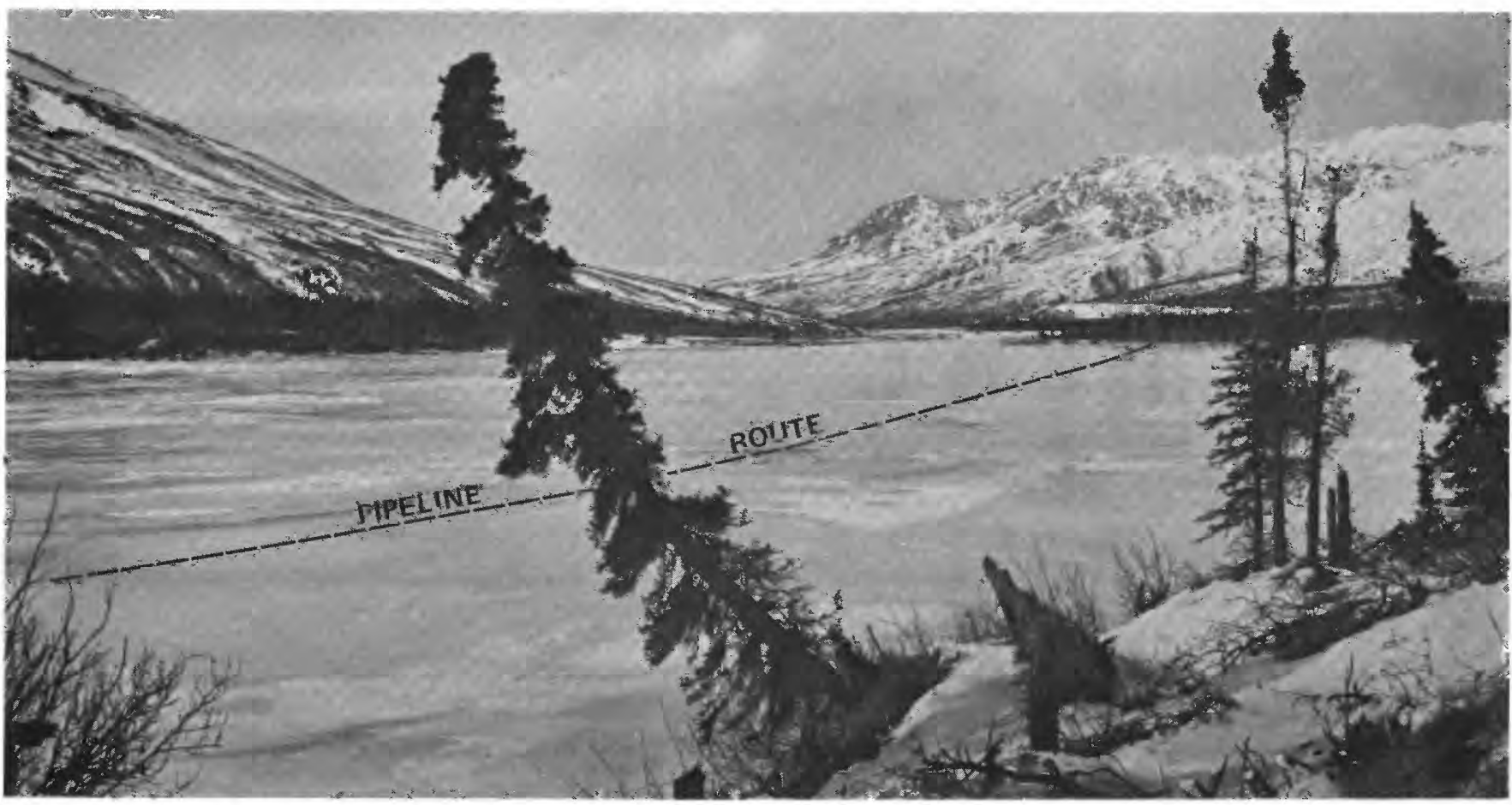

FIGURE 26.-Flood-plain icing in Delta River valley upstream from Miller Creek, April 18, 1974. 


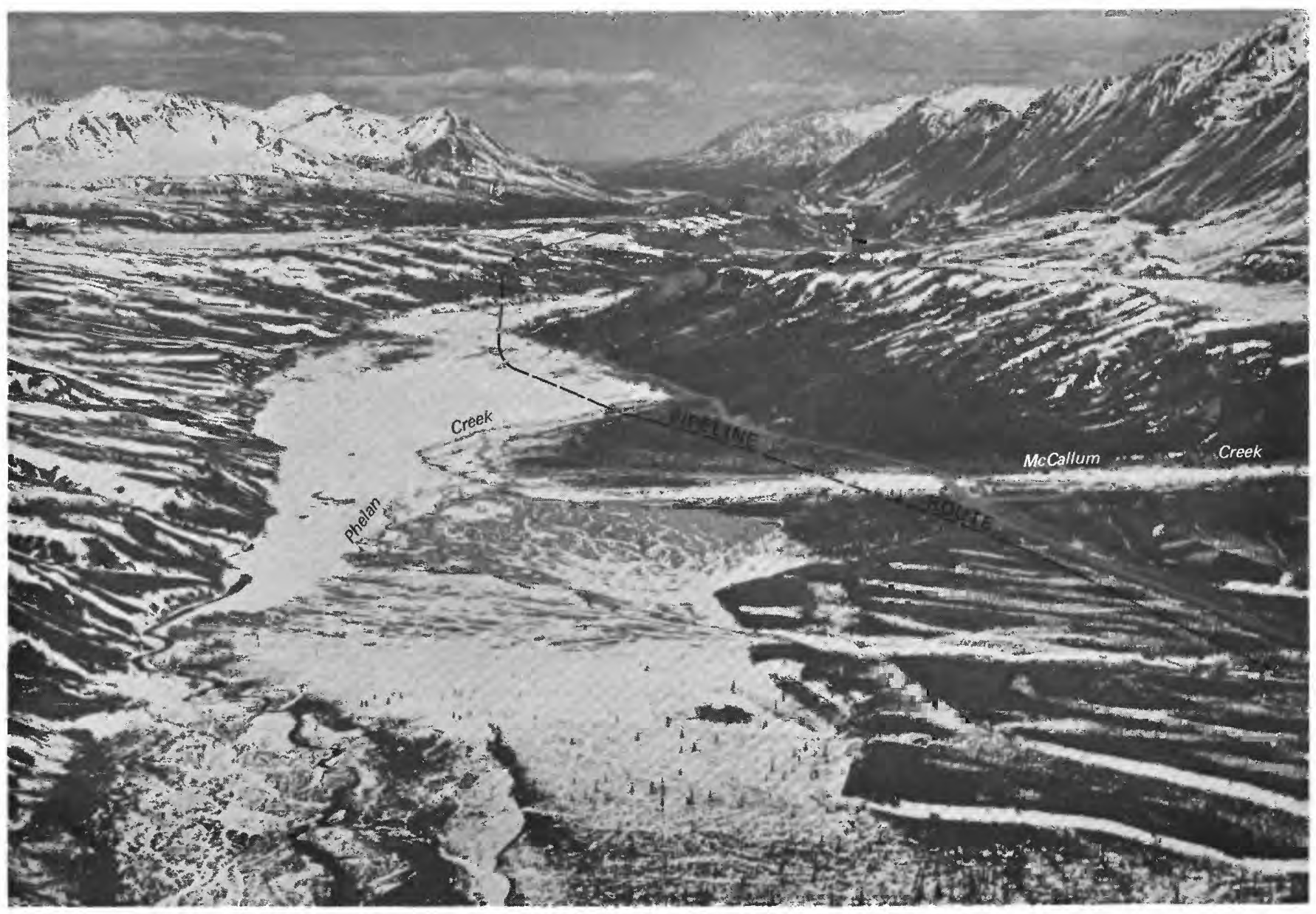

Figure 27.-Icing in Phelan and McCallum Creeks, May 29, 1973.

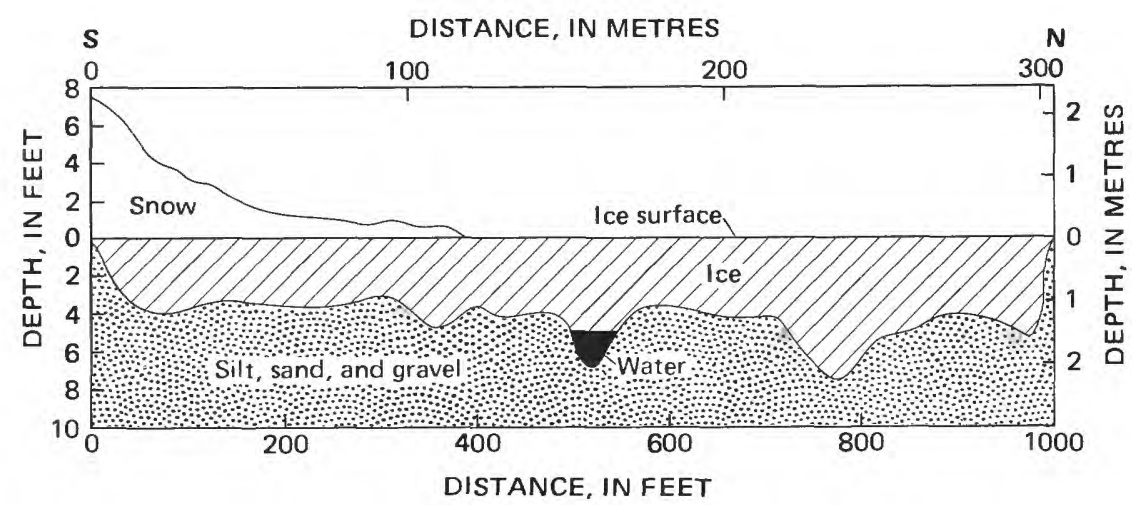

Figure 28.-Cross section through icing at mouth of Phelan Creek, April 27, 1972. (See location of section in fig. 2.) 


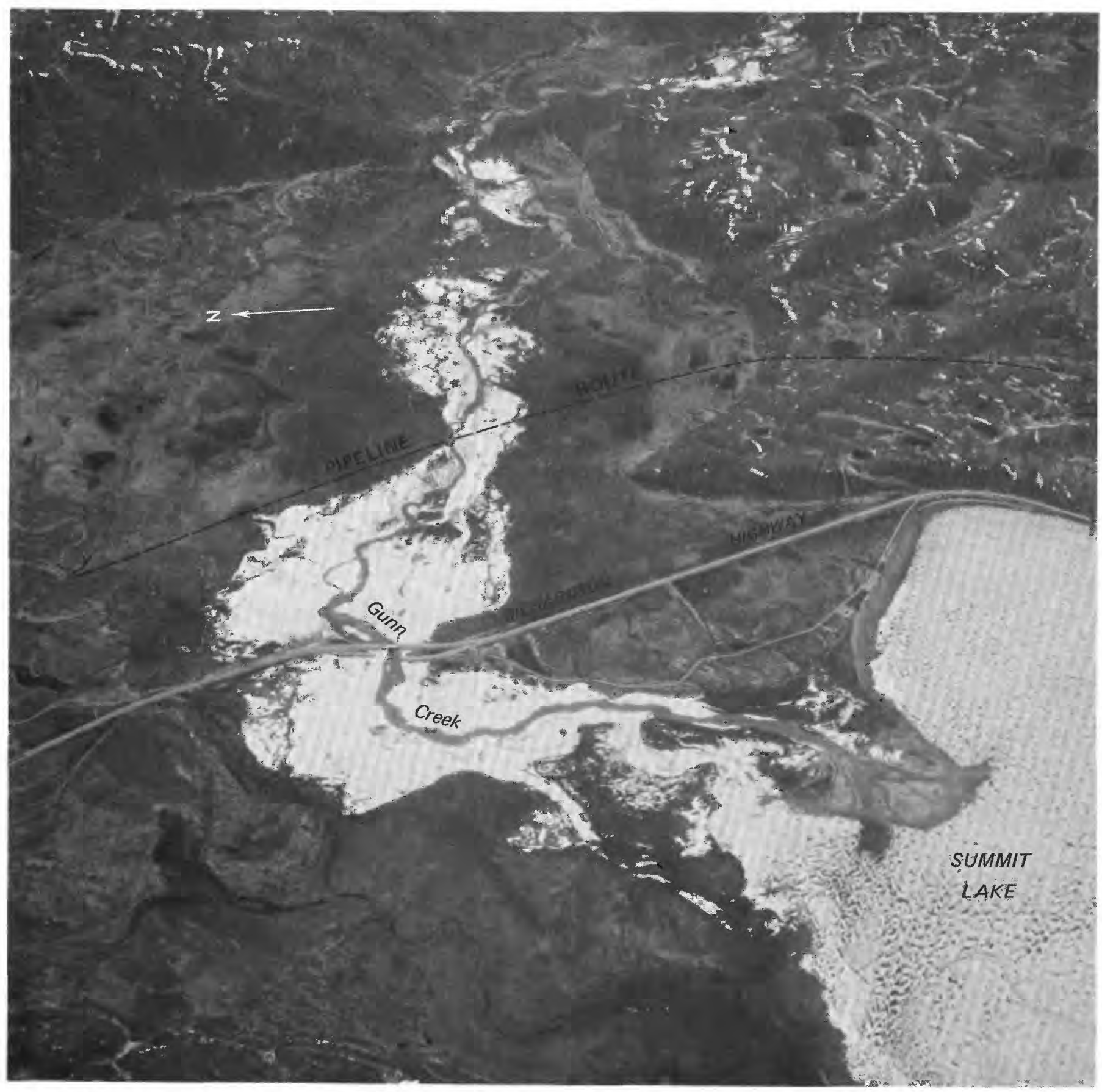

Figure 29.-Icing on Gunn Creek at Richardson Highway and pipeline crossing, June 6, 1970. 


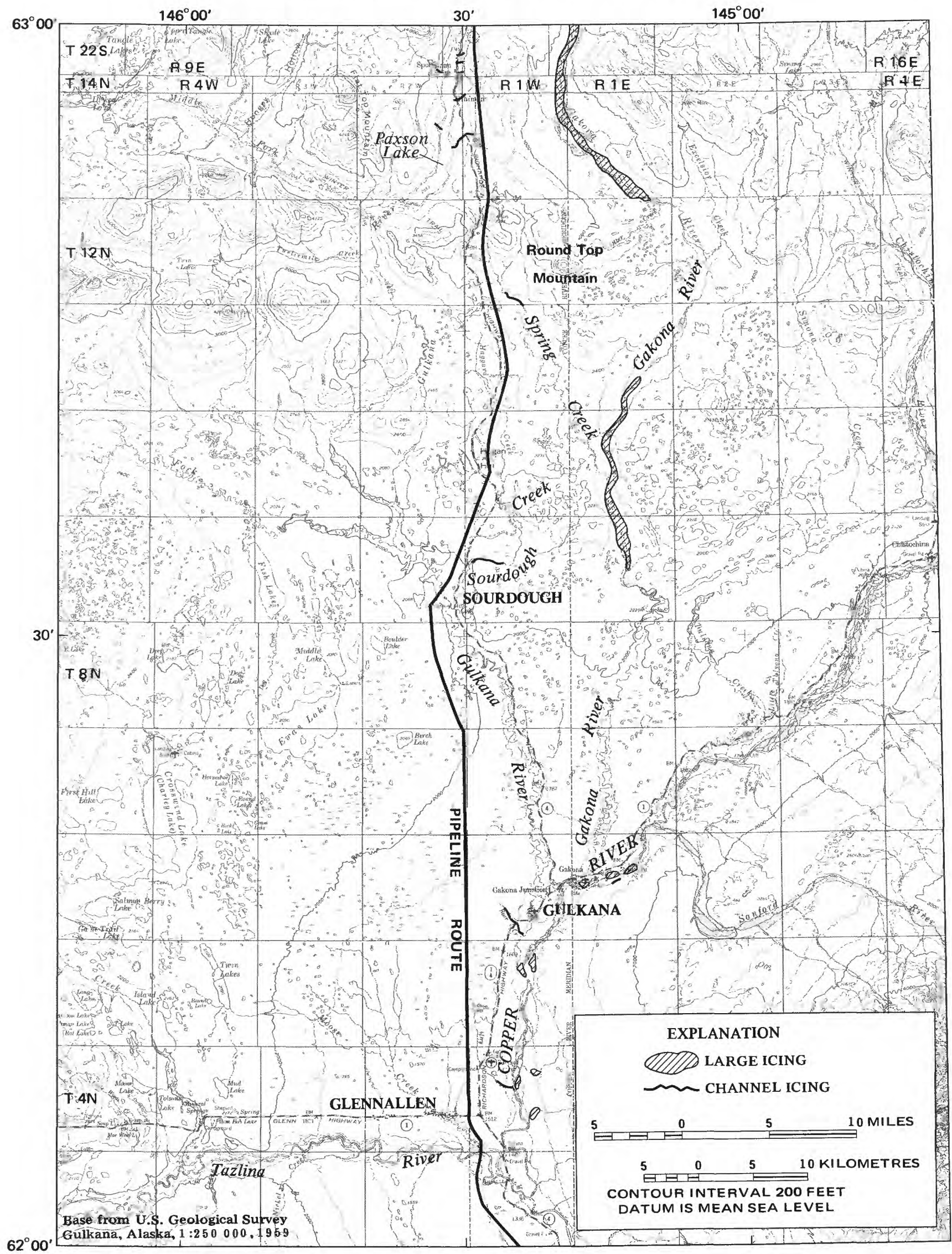

FIGURE 30.-Distribution of icings along the trans-Alaska pipeline route in the Gulkana quadrangle. 


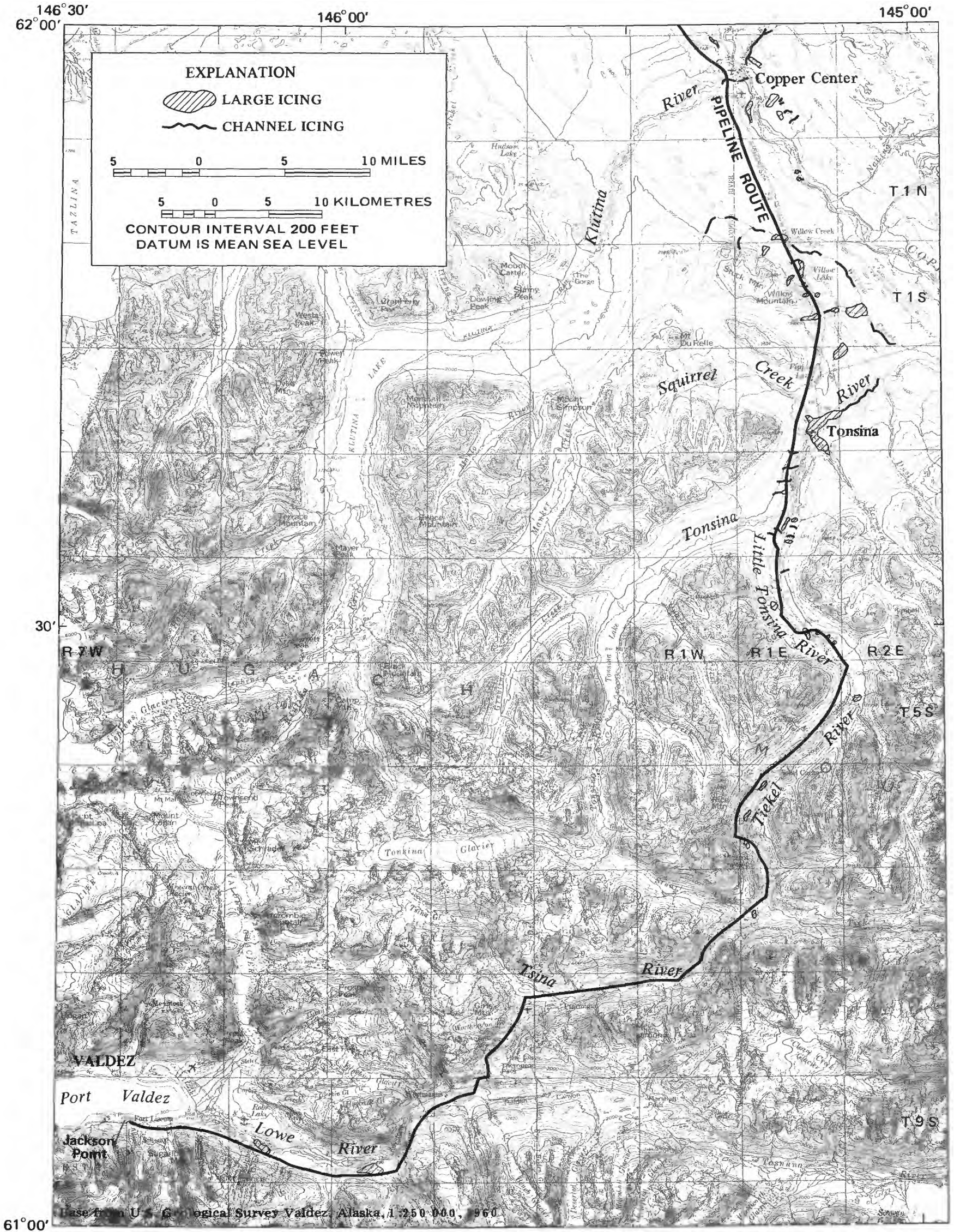

Figure 31.-Distribution of icings along the trans-Alaska pipeline route in the Valdez quadrangle. 


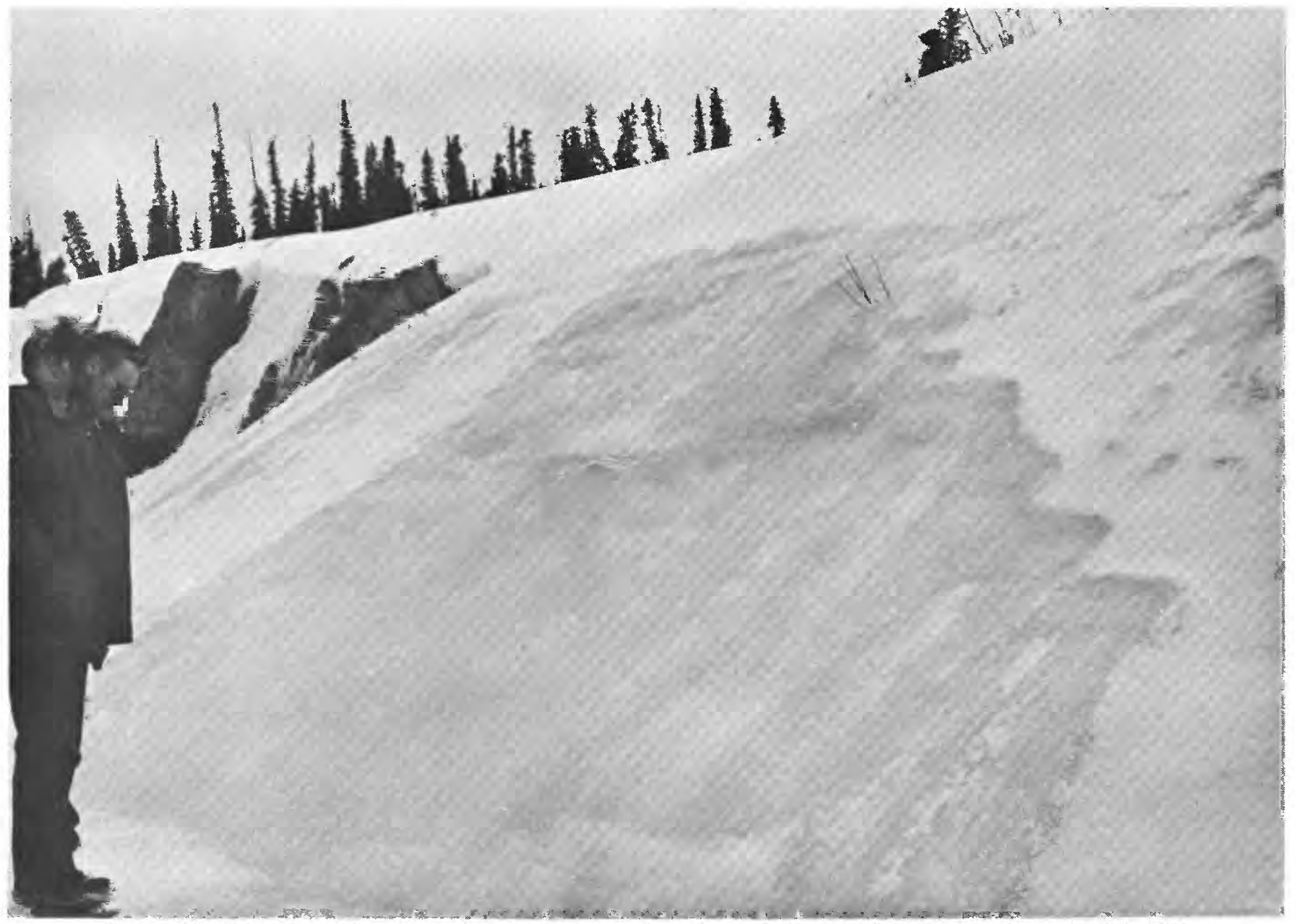

FIGURE 32.-Icing formed from ground-water seepage at face of gravel pit near Little Tonsina River, April 1, 1971. 